\title{
Dakar-Niger. Paesaggi, città, villaggi, architetture lungo la ferrovia del Sahel: una ricerca in corso
}

\author{
Sebastiano Nucifora
}

\section{Abstract}

Nel 1885 il regime coloniale francese inaugurava la ferrovia che avrebbe collegato Dakar a Bamako. Oggi è la Cina che investe in Africa, con un piano finanziario che vale oltre 60 miliardi di dollari. Un colonialismo non più di impronta politica ma economica, friendly e sustainable, che traduce in pratica una equazione semplice: materie prime in cambio di infrastrutture.

Tra queste ultime una particolare attenzione è riservata al potenziamento delle linee ferroviarie africane, come quella che il leggendario Koulikoro percorreva tra Dakar e Bamako, e di cui la compagnia China Railway Construction si è assicurata nel 2015 la commessa di ristrutturazione per quasi 3 miliardi di dollari. Attenzione destinata ad influire non poco sul futuro socioeconomico dell'area e a cambiare nuovamente volto ad un territorio di notevole estensione ed ai numerosi centri urbani presenti lungo la ferrovia che lo attraversa.

Da Keffrine a Tambacounda, tali centri si dibattono ancora tra la dimensione concettuale del grande villaggio e quella della piccola città.

La ricerca in atto si propone di indagare e di classificare i centri presenti lungo la ferrovia e il ruolo che quest'ultima ha avuto nella loro storia urbana, nonché di proporre ipotesi di progetto proprio a partire dai grandi vuoti presenti nelle aree delle stazioni, segnati da malconce architetture coloniali, potenziali matrici di scenari futuri per un vero sviluppo sostenibile, accettato e riconoscibile dalle comunità locali.

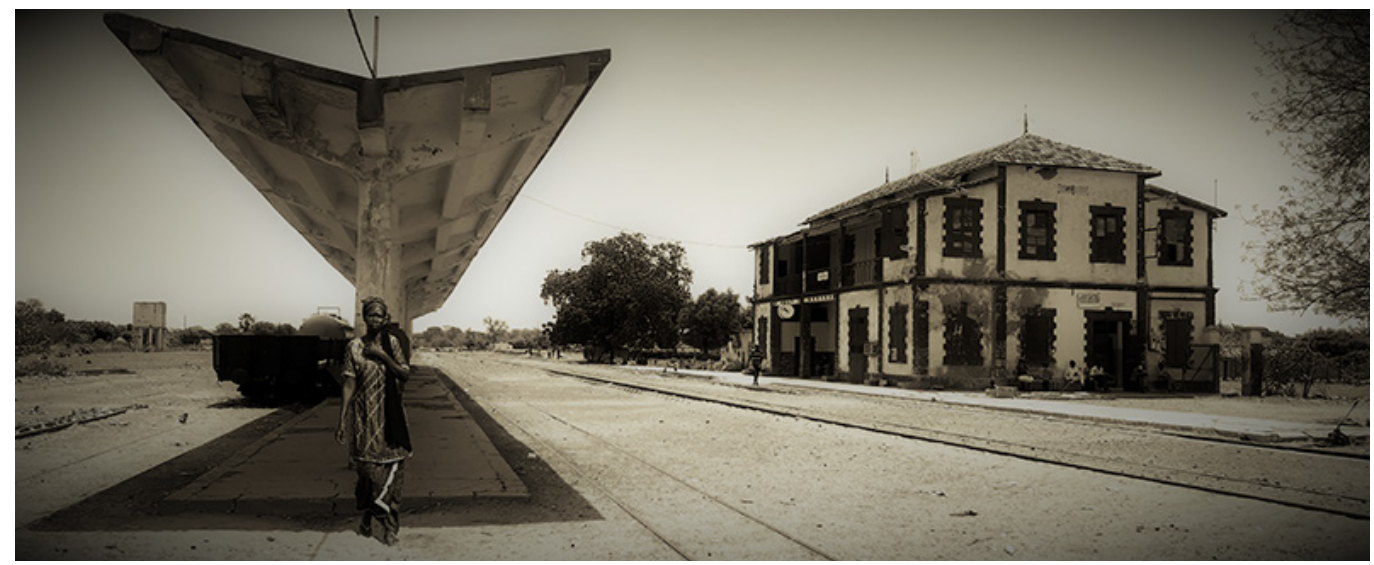




\section{Introduzione, ipotesi di ricerca e metodologia}

I| 6 luglio del I885, venivano inaugurati a Dakar i 263 km di ferrovia che collegavano la nuova alla vecchia capitale coloniale francese del Senegal, Saint Louis. Questo troncone era il primo dei tre messi in cantiere dal piano Freycinet del 1879 che ne prevedeva un secondo, di 498 km, dalla capi-tale del Mali, Bamako, fino a Kayes, al confine tra i due stati, e un terzo, di $648 \mathrm{~km}$, di collegamento tra i primi due, da Kayes fino a Thiés e quindi nuovamente a Dakar. Questo progetto sarà uno dei pochi, in Africa, effettivamente attuato nella sua totalità con la costruzione, rispettivamente, dal I88I al 1904 del secondo tratto e, dal 1905 al 1923, del tratto finale [I]. La Linea faceva parte di un più ampio piano di penetrazione infrastrutturale dell'Africa francofona, capace, nelle intenzioni dei colo-nizzatori, di integrare, economicamente e militarmente i territori del nord, sull'arco del mediterraneo, con quelli dell'ovest, all'interno del continente fino al golfo di Guinea. Tali territori, quello magrebino e quello sub-sahariano, separati non solo fisicamente dalla distesa desertica, sarebbero stati attra-versati da due direttrici, la prima da sud a nord, trans-sahariana, e la seconda, da ovest ad est, trans-africana. L'enormità dell'impresa e le complesse vicende coloniali permisero solo in parte di attuare il piano, lasciando incompiuto il sogno di un attraversamento ferroviario del grande Erg. Tut-te le linee portate a compimento hanno profondamente alterato le logiche insediative dei territori at-traversati e, tra queste, la Saint Louis-Dakar-Bamako ha rappresentato, fin quando è rimasta attiva, la tratta con una maggiore coerenza funzionale, capace di collegare i porti senegalesi sull'oceano Atlantico alle rive del grande fiume Niger. Più di cento anni dopo, conquistata l'indipendenza politica dalle nazioni europee, tutta l'Africa sub-sahariana è oggi soggetta ad una nuova forma di colonialismo ad opera della Cina, con un piano di investimenti che, nel 2018, è valso oltre 60 miliardi di dollari. L'equazione proposta è tanto elemen-tare quanto efficace: materie prime in cambio di infrastrutture.

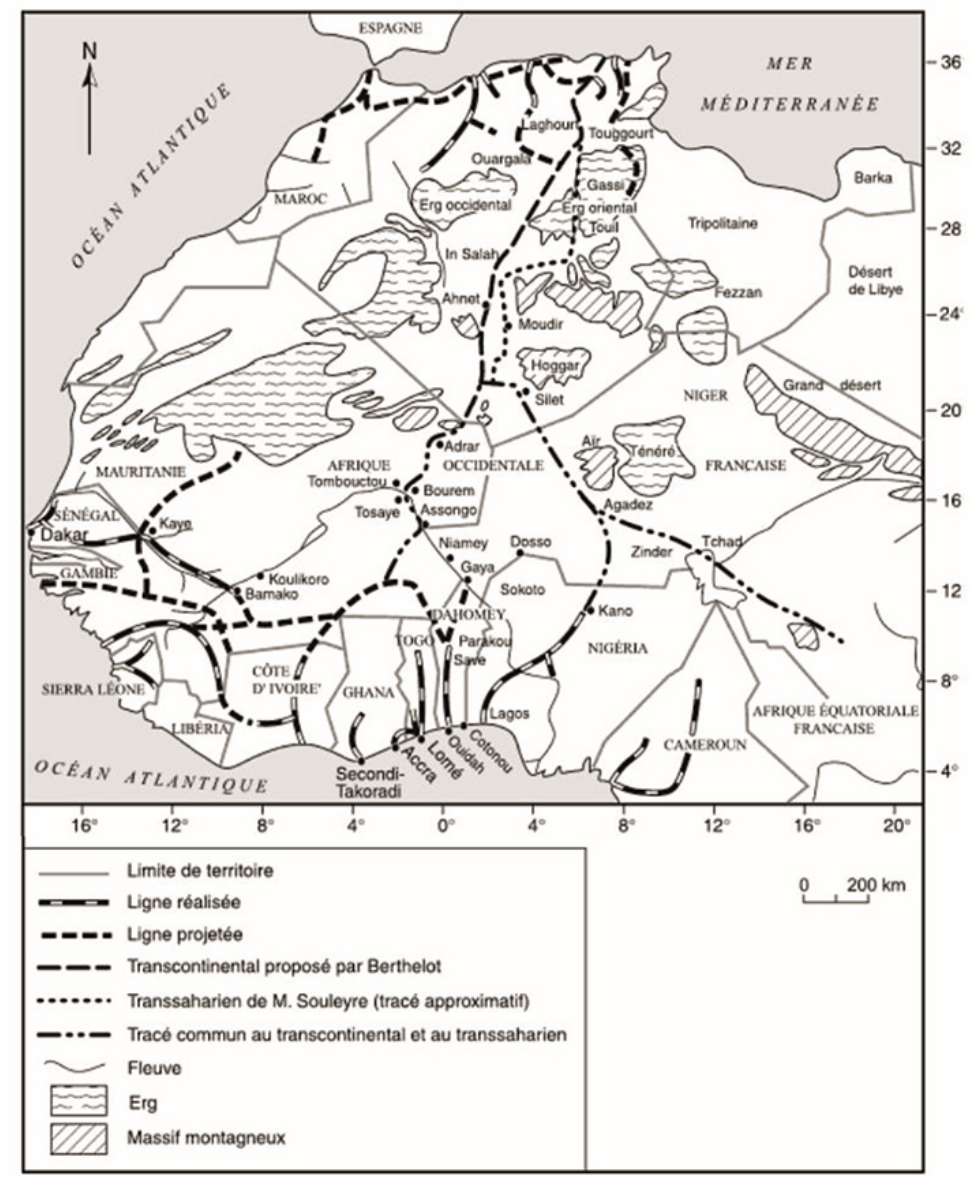


Tra queste infrastrutture, una particolare attenzione è riservata al potenziamento delle linee ferro-viarie [2], molte delle quali sono attualmente dismesse, come quella che il leggendario Koulikoro [3] ha percorso tra Dakar e Bamako dagli inizi del ventesimo secolo fino ai primi anni del ventunesimo. Di questa linea, nel 2015, la compagnia cinese China Railway Construction si è assicurata la com-messa di ristrutturazione per quasi 3 miliardi di dollari. Gli interessi che muovono questa operazio-ne, sono deputati a cambiare nuovamente i destini di una porzione di territorio di notevole estensione.

Da Kaffrine a Tambacounda, da Kita a Badinko, i centri attraversati dai binari, sono rimasti sospesi tra la dimensione del grande villaggio e quella della piccola città, tra una impostazione di matrice co-loniale francese e uno sviluppo informale, dovuto alla mancanza di una vera pianificazione post-coloniale e al rifiuto ancestrale del modello imposto dal colonialismo stesso.

La ricerca in atto si propone, in una prima fase, di indagare e di classificare i centri urbani e i villaggi presenti sulla direttrice Dakar-Bamako ricadenti nel territorio senegalese, demandando ad una fase successiva quelli che si susseguono lungo il percorso parallelo alla costa atlantica tra Dakar e Saint Louis e quelli presenti nel territorio maliano.

Lo studio si occupa di mettere in evidenza il ruolo fondante che la ferrovia ha avuto nella configura-zione dei tessuti urbani, nonché di rilevare e catalogare le malconce architetture coloniali che la puntellano lungo il percorso.

II tentativo è quello della riconnessione paziente della storia pre e post-coloniale di un territorio fragi-le che è, tutt'oggi, alla ricerca di una propria identità. Lo scopo è giungere a progetti utili ad un vero sviluppo sostenibile e accettati dalle comunità locali, laddove le proposte introdotte dai nuovi competitor cinesi preannunciano scenari volti a fare tabula rasa dell'esistente.

La metodologia si articola in cinque punti: ricerca d'archivio di materiale bibliografico, iconografico e cartografico [4]; sopralluoghi e campagne fotografiche delle aree interessate; rilievo diretto con me-todo tradizionale e/o fotogrammetrico delle architetture coloniali più importanti [5]; restituzione dei rilievi e costruzione dei modelli digitali; classificazione critica dei centri e delle architetture [6].
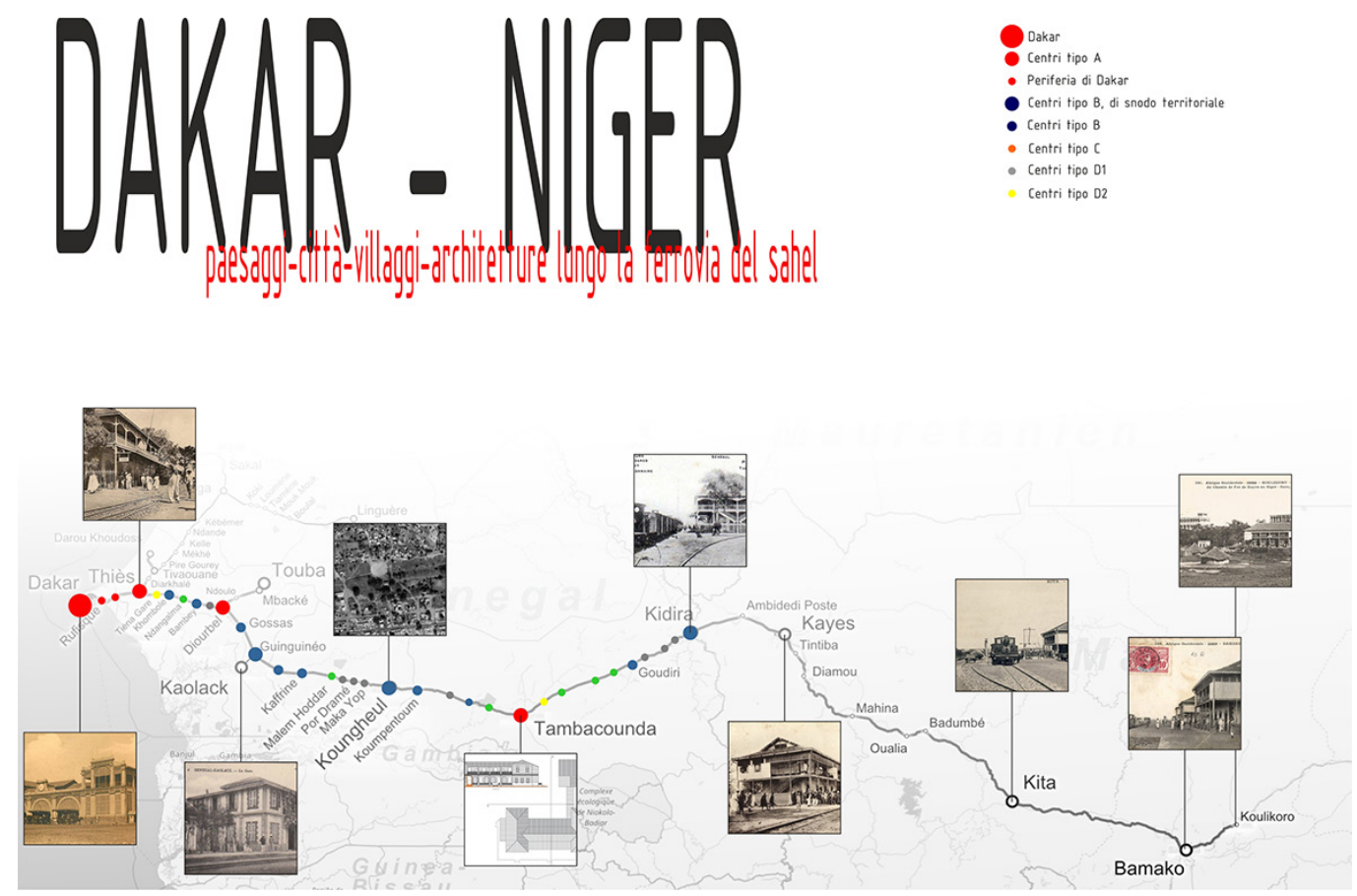


\section{Le città, i villaggi}

Al momento del completamento della linea ferrata, Thiés, la città attualmente più popolosa che si in-contra sul percorso, era un piccolo villaggio di etnia serer in cui i francesi avevano da poco istallato una base militare. II conto degli abitanti non superava le I50 unità [7]. Ad esclusione delle due capi-tali, agglomerati definibili come urbani risultavano assenti nelle mappe tra il Senegal e il Mali. Ė l'arrivo della ferrovia che, di fatto, determina la nascita dei centri lungo il suo percorso. Questo non deve alimentare la teoria che considera la 'città' una creatura estranea al modello abitativo del terri-torio sub-sahariano precoloniale. Lo testimonia la storia stessa di Bamako, o quella dei leggendari centri dei regni del Mali e del Ghana. Si può dimostrare che, dove era possibile reperire materiali la-pidei, i popoli africani hanno saputo costruire monumenti non meno importanti e duraturi di quelli di altre culture. Se il territorio in questione era strutturato da insediamenti rurali sparsi, ciò è riconduci-bile soprattutto a fattori culturali e antropologici derivanti dalle caratteristiche più o meno stanziali delle etnie che li abitavano, oltre che, ovviamente, ad un dato più strettamente naturale.
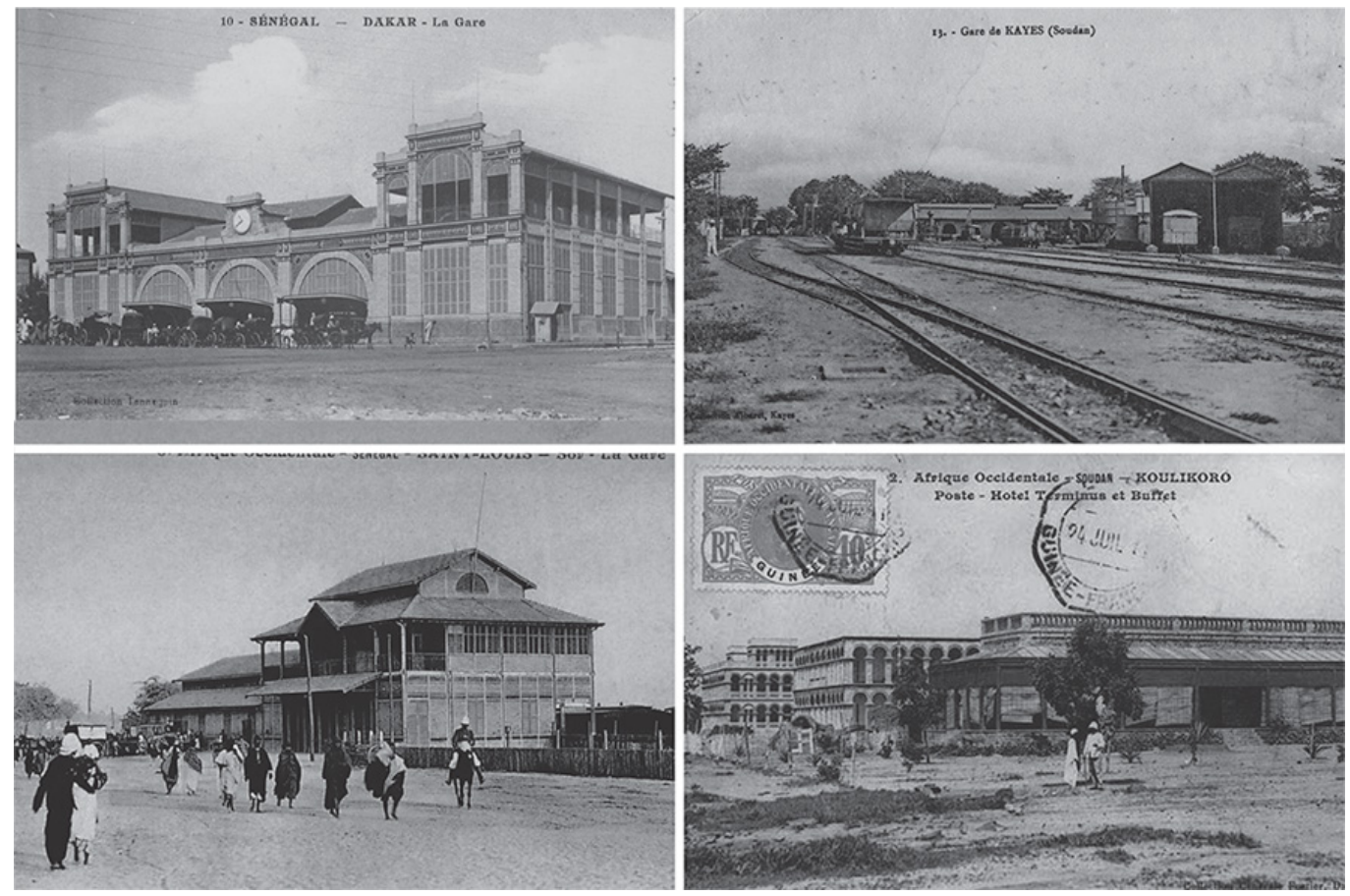

Il vallo ferroviario si insedia quasi sempre in un luogo vergine, divenendo l'elemento generatore di un nuovo abitato che funge da catalizzatore per le popolazioni rurali delle aree limitrofe. La città co-loniale verrà pianificata sulla misura del vallo, con un rigido impianto a maglia ortogonale, come si registra, soprattutto, nella maggioranza dei centri senegalesi. Diverso è il caso dei centri del territo-rio maliano, dove la morfologia più articolata dovuta alla presenza di fiumi e rilievi, unita ad una cul-tura urbana autoctona, daranno vita ad impianti di natura più complessa.

Limitandosi ai centri senegalesi [8], si è proceduto ad una classificazione basata sullincrocio di tre parametri: la grandezza e l'importanza territoriale del centro, la tipologia dell'impianto urbano, la con-figurazione dell'area ferroviaria sulla base della presenza o meno delle strutture edilizie ad essa relative. 
Fig. 4. Schemi di alcuni centri di tipo A e di tipo B. In nero l'impianto

rancese con il grande

unoto del vallo ferroviario; mercato.

Fig. 5. Schemi di alcuni centri di tipo C e D.
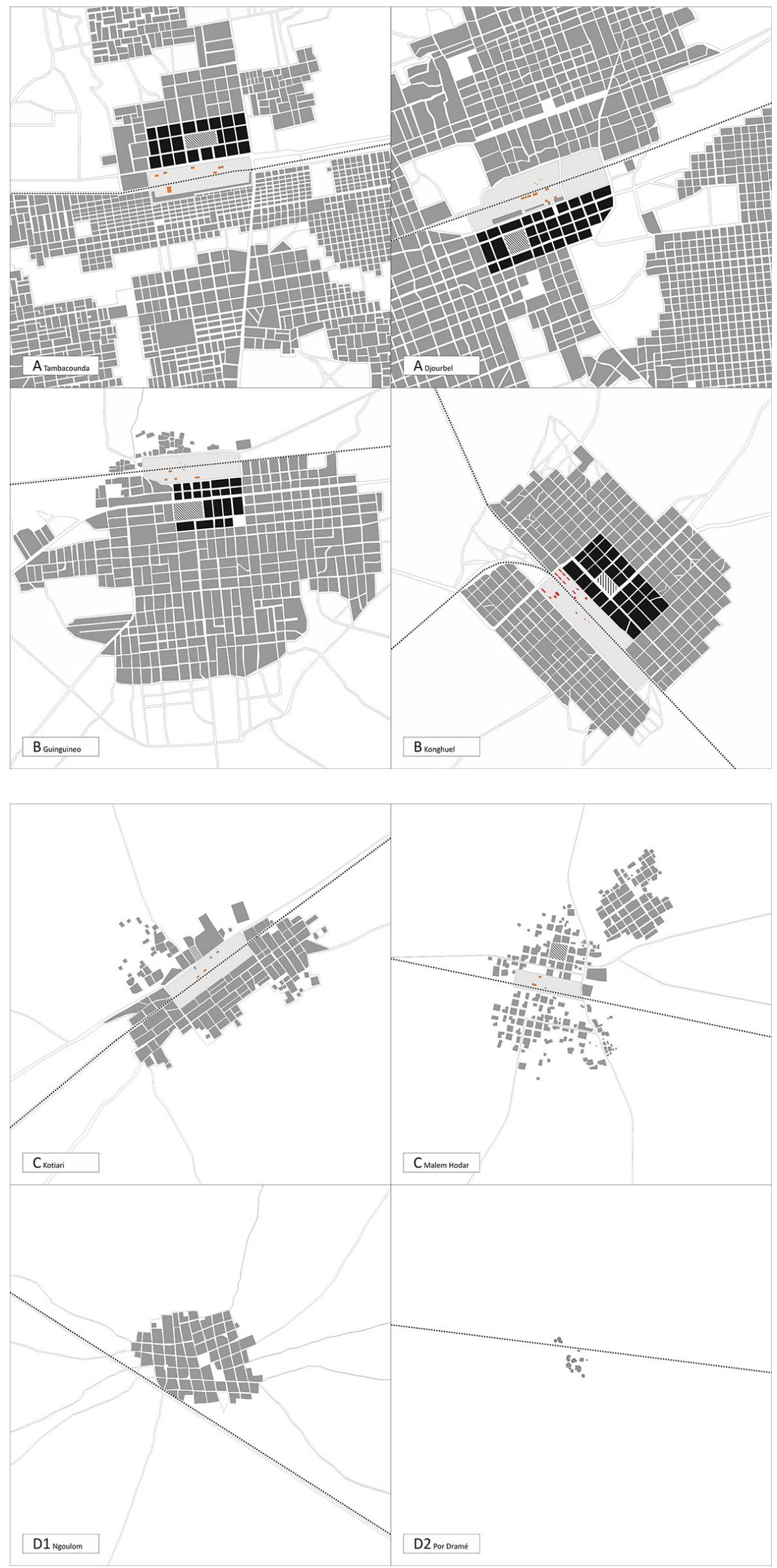
Lungo il percorso possono individuarsi quattro tipologie:

Centri di tipo A:Thiés, Diourbel, Tambacounda.

Sono centri di media e grande importanza che, proprio per la loro posizione territoriale strategica, erano probabilmente già sede di villaggi rurali. L'arrivo della linea ferroviaria ne ribadisce la posizio-ne ma, con la definizione planimetrica del vallo della stazione, viene stabilita una maglia di impianto ortogonale che, di fatto, ne trasforma le caratteristiche da rurali a urbane, soppiantando la tipologia del villaggio spontaneo.

La maglia disegnata dai francesi definisce la misura dell'isolato ma, ad esclusione di alcuni lotti in cui sono presenti gli edifici amministrativi di impronta coloniale che ne delimitano il perimetro, il con-torno del lotto diventa di fatto un recinto basso, come nella tradizione dei villaggi rurali, all'interno del quale si muovono liberamente le costruzioni.

Nei centri di tipo A, vista la loro importanza, l'area della stazione risulta completa di quasi tutte le strutture e le funzioni.
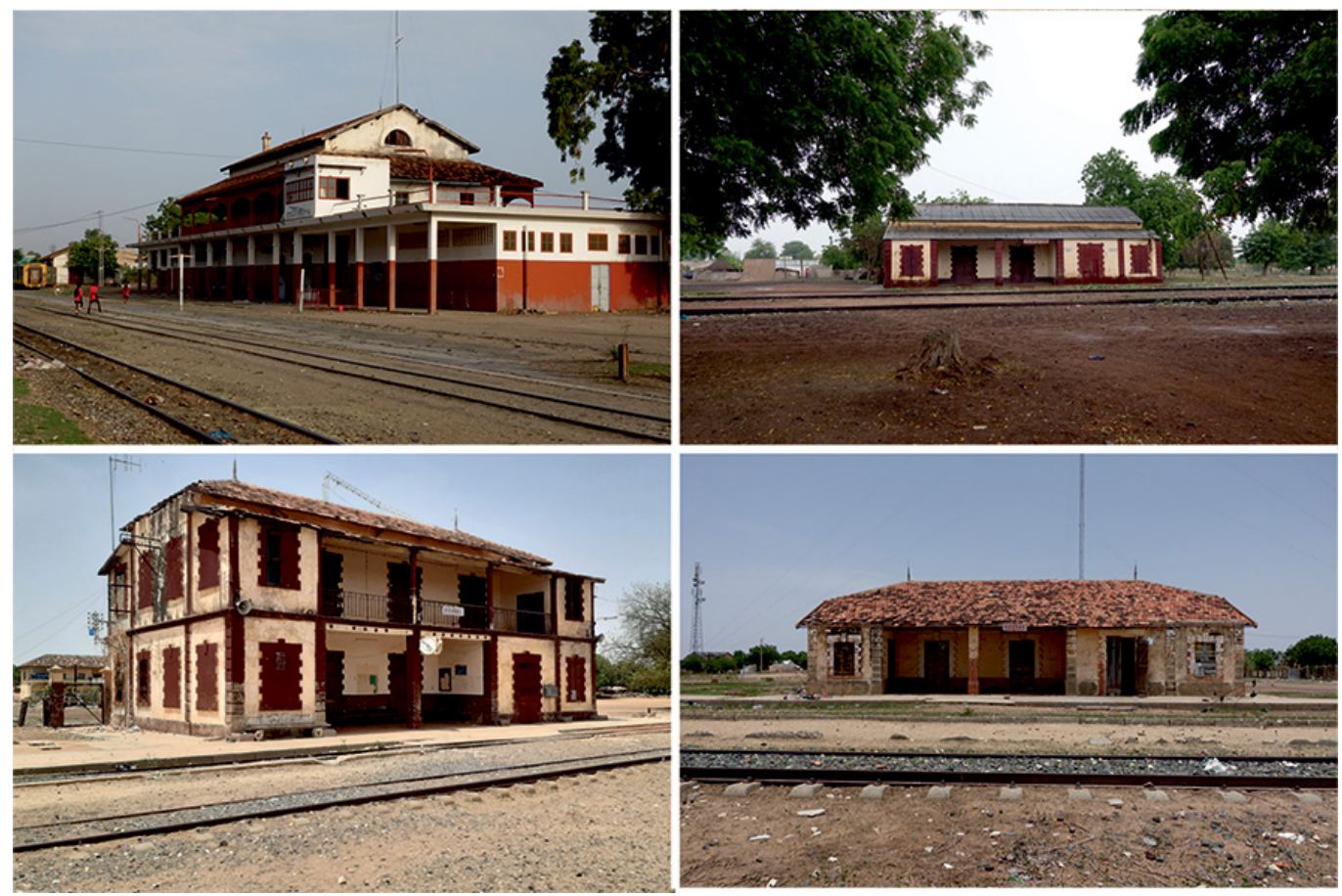

Poiché sono centri di distribuzione territoriale da cui si dipartono direttrici secondarie di innervamen-to, il tessuto di impianto si evolve, nel tempo, in maniera più o meno articolata rispetto alla semplice maglia ortogonale.

Delle tre, Thiés, anche in virtù della sua vicinanza a Dakar, è certamente la più importante, sia per posizione strategica sia per estensione, ed è l'unica che può elevarsi al rango di città. Nonostante il notevole sviluppo urbano abbia prodotto un tessuto multipolare, derivante dalla posizione nodale del centro rispetto al territorio, è ancora chiaramente riconoscibile il polo d'impianto originario del piano coloniale francese, di cui lo scalo ferroviario ne è l'elemento cardine. Più regolari i tessuti urbani di Diourbel e di Tambacounda, sebbene anche queste due cittadine si caratterizzino come punti di snodo territoriale: verso la città santa di Touba la prima, verso il Casamance la seconda.

Centri di tipo B: Khombole, Bambey, Gossas, Guinguineo, Birkelane, Kaffrine, Kongheul, Koumpetoun, Goudiri e Kidira. 
Sono centri di piccola e media dimensione e importanza e sono, a parte l'eccezione di Kaffrine [9], centri di nuova fondazione. Lo scalo più importante era quello di Guinguineo, punto di snodo verso Kaolach e il Gambia. Insediati nei luoghi che il potere francese riteneva di importanza strategica, si caratterizzano per il tessuto regolare generato dalla giacitura e dalla misura del vallo ferroviario. L'impianto urbano è sempre di tipo ortogonale. Quando si riscontrano scarti consistenti rispetto alla maglia d'impianto, ciò è dovuto all'orientamento della strada nazionale RNI [I0] che, a tratti, non re-sta parallela alla ferrovia. Tra questi centri, un caso anomalo è rappresentato dal tessuto urbano di Kidira, città frontaliera tra il Senegal e il Mali che, seguendo l'andamento del fiume Falémé, confine tra i due stati, segue logiche insediative diverse. In tutti questi centri, l'area della stazione presenta una complessità funzionale variabile caso per caso.

Centri di tipo C: Dangalma, Malem Hoddar, Sinthiou Malem, Koussanar, Kotiari, Bala, Boughieul Bamba.

Sono centri di piccola dimensione che hanno avuto una crescita minore rispetto a quelli di tipo $\mathrm{B}$, in cui si legge comunque la presenza del vallo ferroviario e risulta leggibile la pianificazione della ma-glia ortogonale. Tra questi, fa eccezione Boughiel Bamba, in cui l'impronta planimetrica dell'insediamento resta quella caratteristica del villaggio rurale. Nell'area ferroviaria di questa tipolo-gia di centri si rivela la presenza del solo edificio della stazione e, al più, di qualche magazzino.

Fig. 7. Magazzino di Rialzo di Tambacounda e Case dei ferrovieri di Gossas, Bambey, Kaffrine.
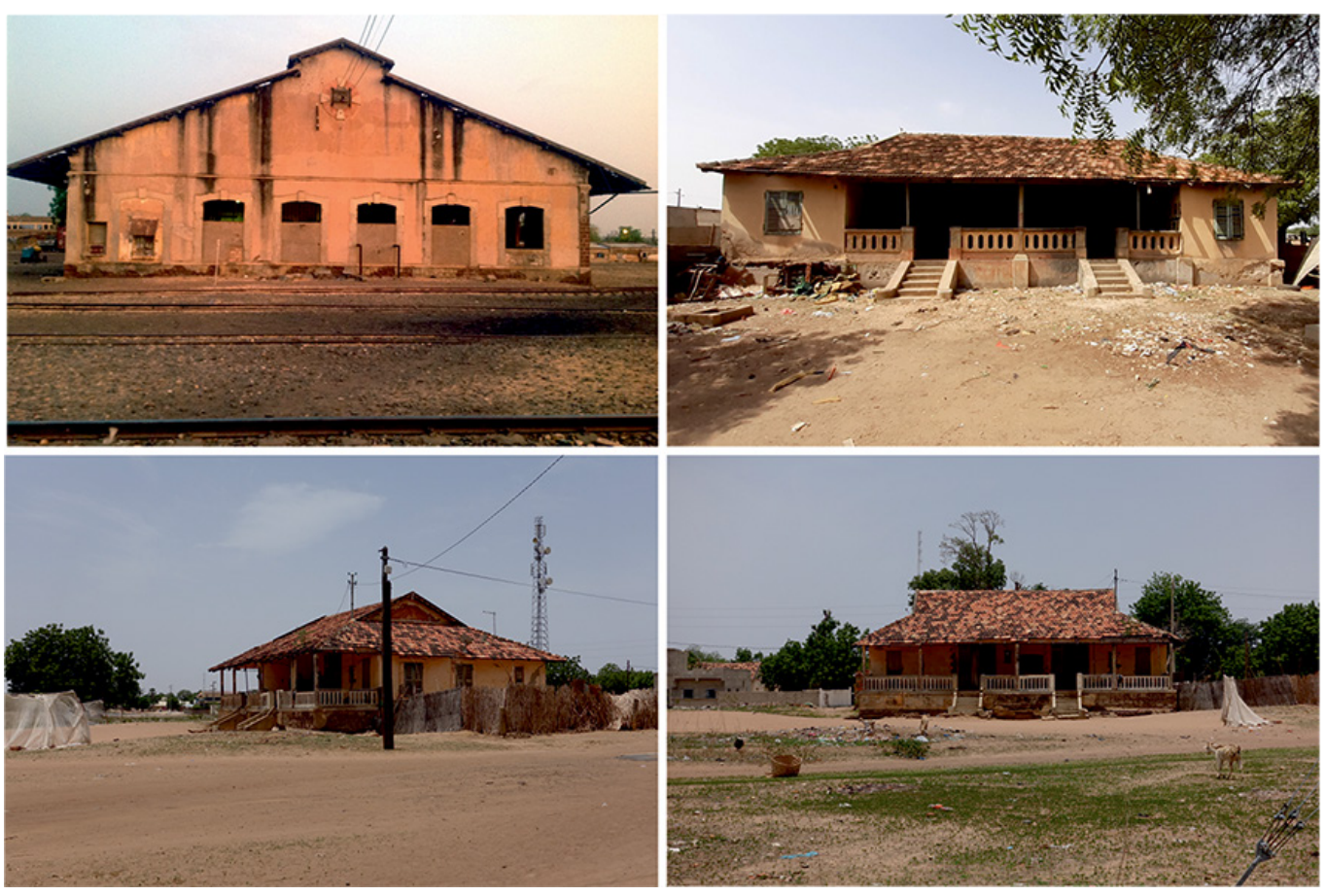

Centri di tipo D: Sono i numerosi centri di piccolissime dimensioni definibili come villaggi, che si formano quasi tutti successivamente alla nascita della linea ferrata. Si possono distinguere a pro-pria volta in due tipologie: $\mathrm{DI}$, in cui è riscontrabile una pianificazione minima con divisione dei lotti a maglia ortogonale come a Ngoulom, e D2, che mantengono in toto la struttura del villaggio rurale come ad esempio Por Dramé.

Non sono luoghi che il progetto coloniale riteneva strategici per il controllo e le dinamiche dei tra-sporti del territorio, e non vi si riscontra la presenza di alcuna struttura edilizia legata alla ferrovia se non, qualche volta, il solo edificio della stazione, come, ad esempio, a Lagnar, Maka Yop e Por Dramé. Più che di fondazione, la linea ferrata ha qui avuto una funzione catalizzatrice, spingendo alla formazione di villaggi a cavallo della linea stessa, laddove prima non ve ne era presenza. Dalle indagini dirette si è rilevato che, in alcuni di essi, pur non essendo prevista la fermata ufficiale del treno, "a richiesta" tale fermata veniva di fatto effettuata. Ciò spiega la spinta all'accentramento dell'insediamento a ridosso della linea. 
Fig. 8. Hotel de la Gare di
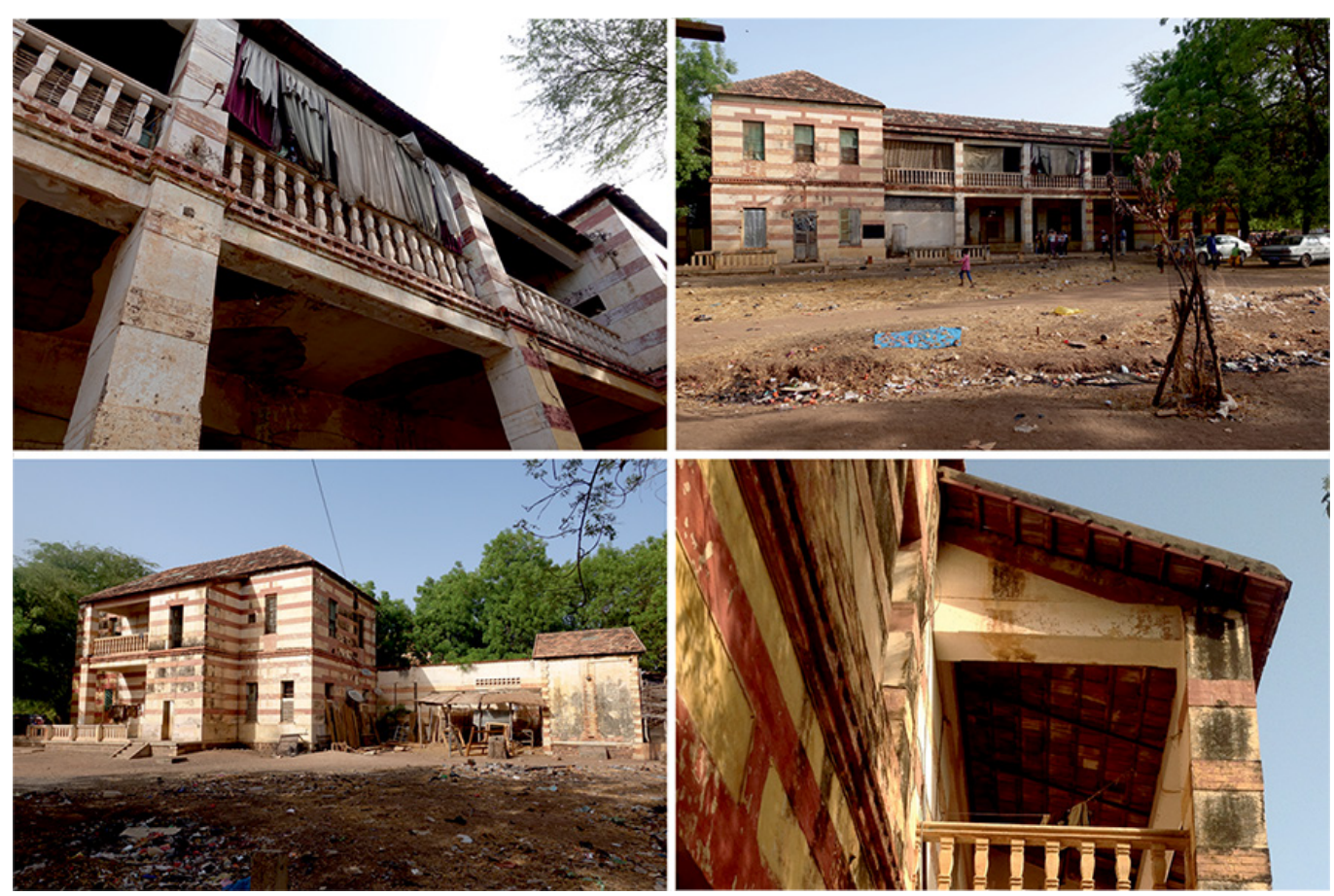

Fig 9. Prefettura diTam-
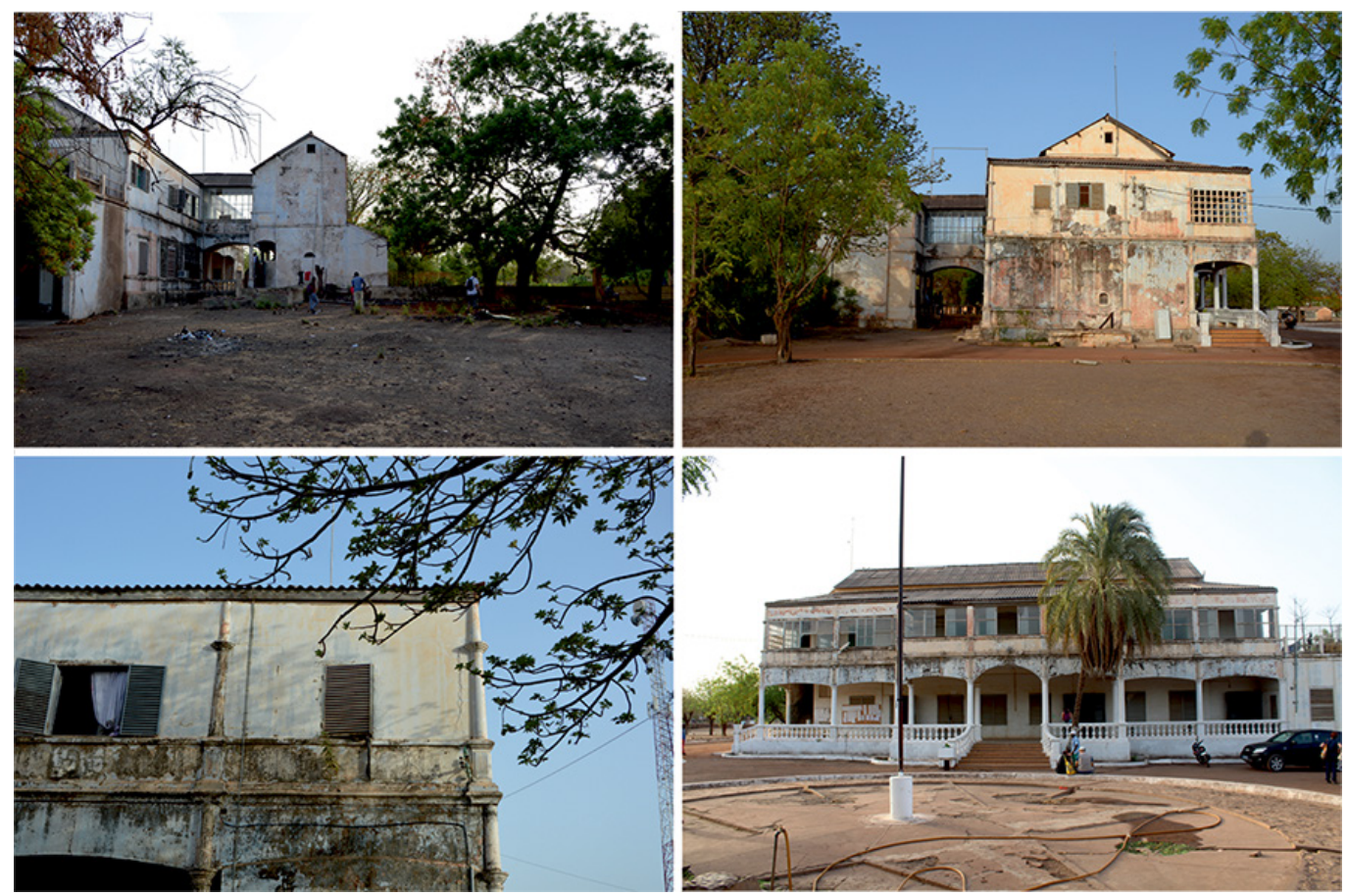
Sia nei centri di tipo A sia in quelli di tipo B, la caratteristica più rilevante è la presenza del "grande vuoto" dell'area ferroviaria.

La dimensione del vuoto è costante in tutti i centri, sviluppandosi in un rettangolo che varia da 700-800 m di lunghezza, a 250-300 metri di larghezza. La misura in lunghezza rappresenta il fronte della città coloniale, che va di norma ad impiantarsi su uno solo dei due lati del vallo, con il posiziona-mento degli edifici amministrativi e la collocazione dell'area del mercato nelle immediate vicinanze.

In alcuni casi, sul lato opposto, divisa dalla ferrovia, si sviluppa la 'città africana', caratterizzata da un tessuto più minuto. Questa tipo di divisione tra città coloniale e città africana è molto evidente nel caso di Tambacounda. Qui, a nord della linea ferrata si collocano gli edifici amministrativi, alcuni di notevole interesse architettonico e tipologico come la Prefettura, in lotti a maglia ortogonale quadra-ta di 95 metri di lato, mentre a sud il tessuto minuto delle abitazioni si sviluppa all'interno di lotti ret-tangolari di 50×30 metri.
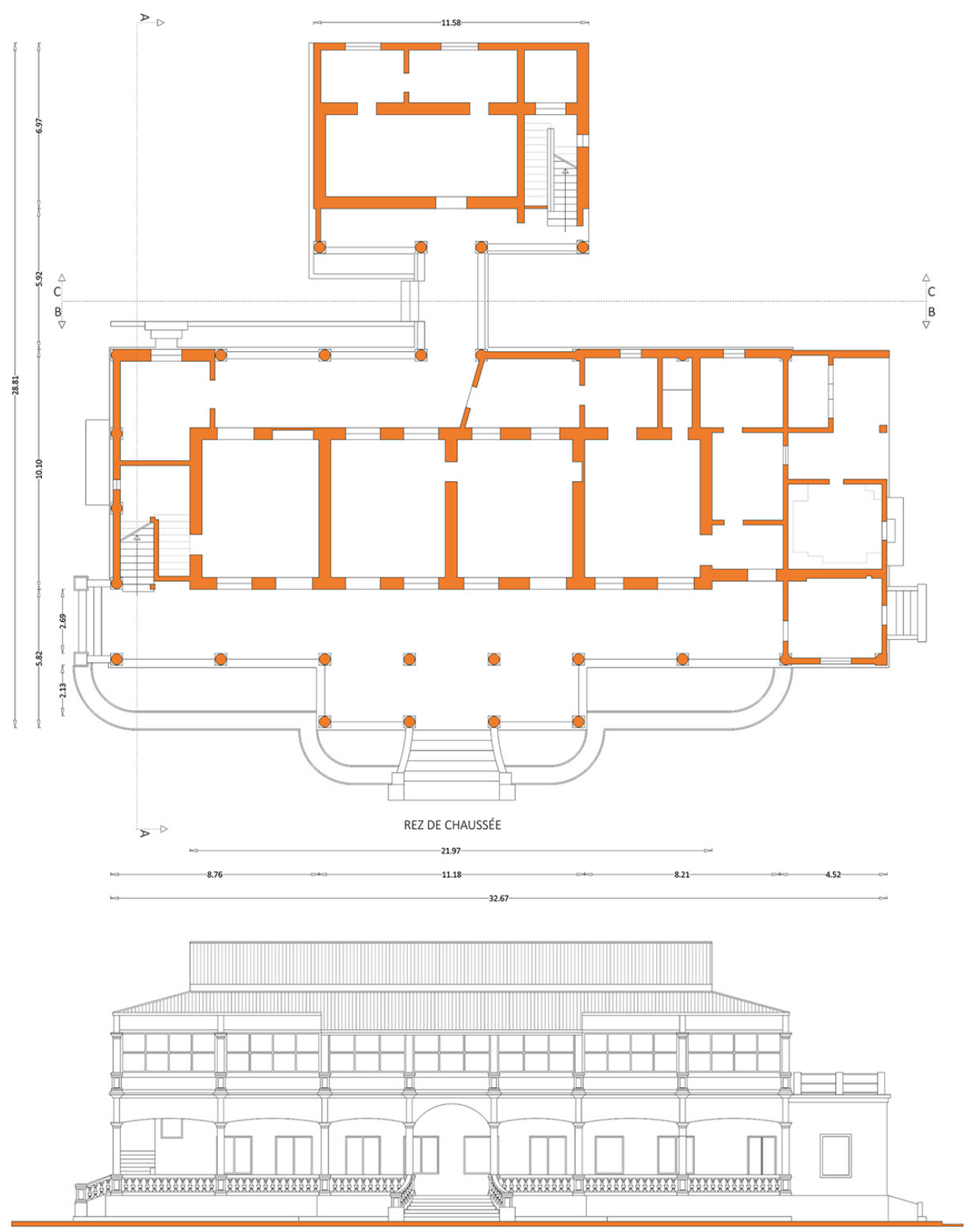

FAÇADE SUD 


\section{Le architetture}

Nel grande vuoto insistono gli edifici coloniali della ferrovia, divisi per tipologie funzionali ma acco-munati da un linguaggio architettonico e da un uso comune dei materiali. Nella configurazione com-pleta, riscontrabile per altro solo a Tambacounda, si possono elencare: Edificio della stazione. È una costruzione ad uno o, nei centri più importanti, a doppio piano, caratte-rizzata dalla presenza di una zona loggiata.

Magazzino di Rialzo. E il grande hangar posto in posizione decentrata rispetto al vallo.
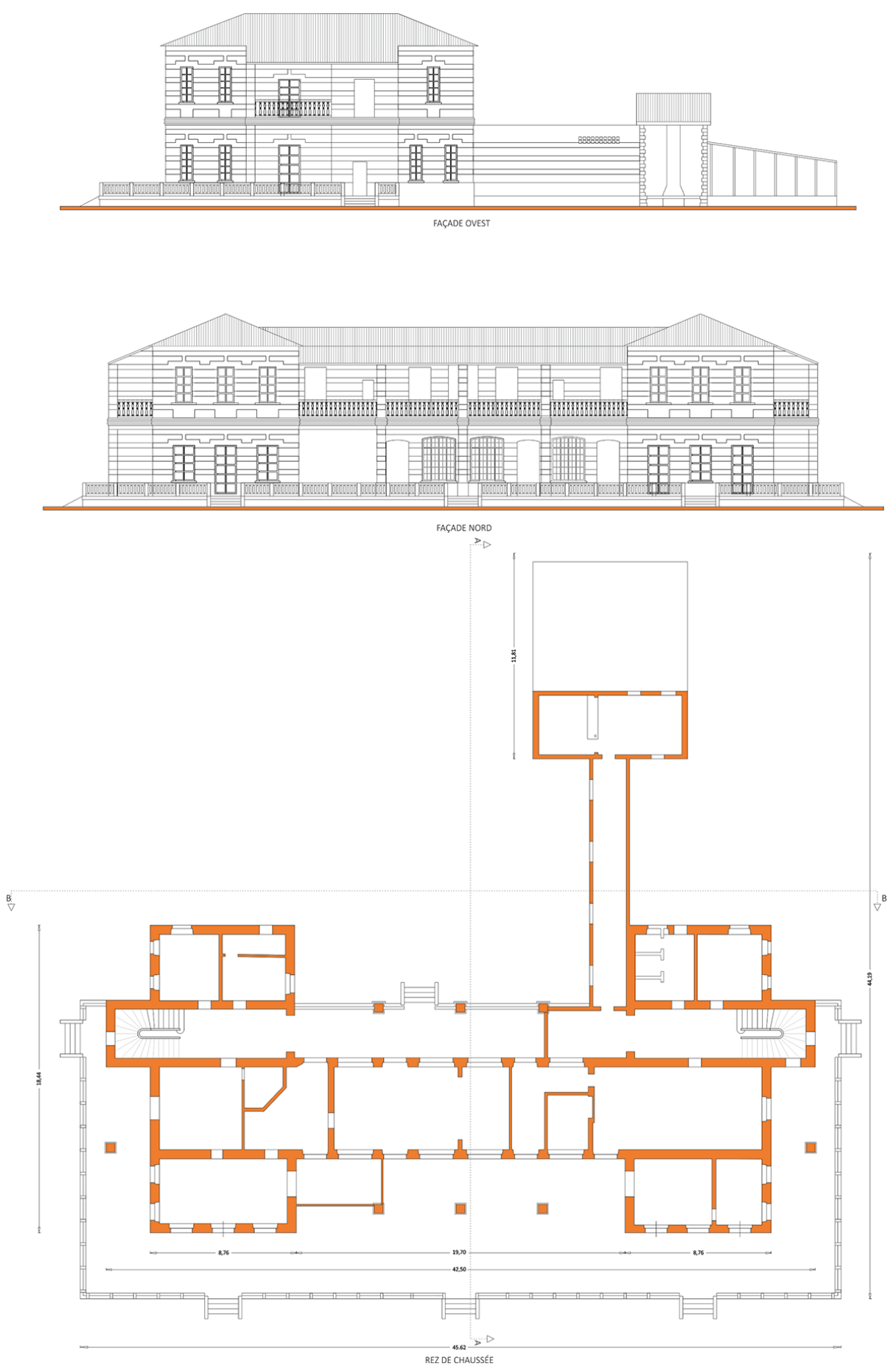
Magazzino merci. È una costruzione ad un piano e a vano unico, in numero variabile sulla base dell'importanza dello scalo.

Alloggi dei ferrovieri. Collocati di norma lungo il margine esterno del vallo ferroviario, a contatto con la strada principale del centro, sono di tipologie diverse, ad uno o a due piani. Hotel della stazione. Soltanto a Tambacounda, si rivela la presenza di un "Hotel de la gare" posizio-nato all'interno del vallo ferroviario. II linguaggio architettonico rende evidente l'appartenenza al me-desimo progetto della stazione.

Torre dell'acqua. Dalla forma cilindrica sostenuta da archi in serie, possono essere una o più. Servizi igienici. Collocati all'esterno degli edifici, in piccoli casotti isolati.

Luoghi di preghiera. Piccoli recinti aperti, con una sorta di abside rivolto verso la mecca.

\section{Conclusioni}

A quanto risulta dall'indagine effettuata, molti degli edifici legati alla ferrovia, sono, sulla carta, consi-derati come beni architettonici vincolati dalle locali Soprintendenze anche se, di fatto, versano in stato di totale abbandono. II restauro e la riabilitazione di queste architetture possono essere un'occasione importante per molti dei centri analizzati, soprattutto se considerati all'interno di una sistemazione urbana di tutto il "grande vuoto". Risulta chiaro che, in virtù di mutate esigenze, quest'ultimo rappresenta un'area strategica tutta da ripensare in vista di una probabile riattivazione della linea ferrata. Progetti appropriati risulterebbero, infatti, fondamentali alla creazione di nuove opportunità di riqualificazione urbana, capaci di integrare i vecchi interventi coloniali ai bisogni con-divisi delle comunità locali.
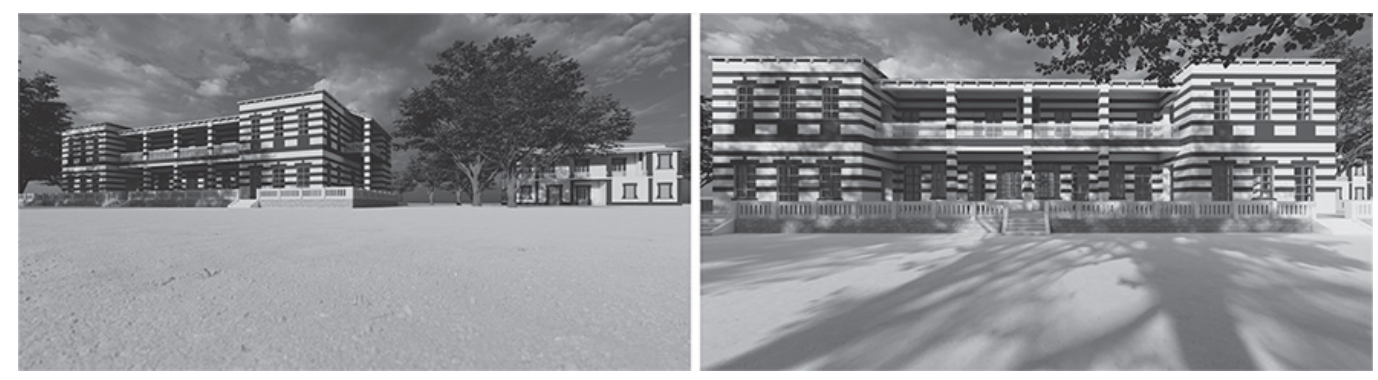

Note

[I] Altre tre diramazioni minori verranno in seguito realizzate nel territorio senegalese: nel 1912 la Guinguineo-Kaolack, nel 1928 la Louga-Linguere e nel 1931 la Djourbel-Touba.

[2] "Sono almeno tre gli indicatori che ci spingono a ritenere che le ferrovie africane siano all'alba di una nuova stagione dopo i decenni di abbandono del passato. II primo è che la vocazione all'esportazione di materie prime... Tutte queste merci avranno bisogno di raggiungere i porti in maniera rapida e sicura. II secondo elemento è la crescita demografica africana e il continuo sviluppo urbano. Le città africane diverranno sempre più grandi, e più numerose saranno le metropoli o le città satellite. Un fenomeno che sta spingendo non pochi governi a immaginare metropolitane, tranvie, ferrovie leggere... Terzo elemento è il maggior peso del commercio intra-africano" [Zaurrini 2015, p. 4].

[3] Nome col quale il convoglio era conosciuto e che riprende quello del centro capolinea, porto fluviale del Niger, situato qualche decina di $\mathrm{km}$ ad est di Bamako.

[4] Questa fase è stata espletata, oltre che sul web, nelle sedi delle amministrazioni senegalesi interessate, compresa la biblioteca dell'Institut Polytechnique Panafricain di Dakar. Si evidenzia, in tal senso, la mancanza di qualsivoglia do-cumentazione grafica preesistente. Tale mancanza rafforza la necessità di un urgente lavoro di catalogazione e rilievo delle architetture coloniali in questione. Una successiva fase di ricerca d'archivio, non ancora compiuta, riguarda la ricerca della produzione manualistica francese ottocentesca, a cui con tutta certezza le architetture delle stazioni se-negalesi fanno riferimento.

[5] Sono stati effettuati due sopralluoghi (luglio 2017, agosto 2019), ripercorrendo la linea ferroviaria da Dakar fino a Goudiri, compiendo una esaustiva campagna fotografica di tutti i centri interessati e, a campione, i rilievi di un buon numero di architetture. É previsto un terzo sopralluogo con la relativa campagna di rilievo, entro il 2020.

[6] La fase della restituzione e della costruzione dei modelli digitali, nonché della classificazione critica dei centri urbani e delle architetture è in corso di svolgimento. 
[7] Thiés è attualmente la terza città del Senegal per numero di abitanti dopo Dakar e Saint Louis, con più di 1.000 .000 di residenti.

[8] La ricerca non si occupa di indagare la capitale Dakar poiché molto più complesse e molto più profonde nel tempo sono, in questo caso, le dinamiche insediative, per ricondurle alla presenza delle sole strutture ferroviarie, che pure hanno contribuito al loro sviluppo.

[9] Qui è certa la preesistenza di un villaggio di etnia serer.

[I0] La Route National I, attraversa il Senegal da ovest ad est, ed è, di fatto, la responsabile del decadimento progressivo del trasporto su rotaie, come spiegano bene Michel Lesourd e Olivier Ninot: "Après les fleuves Sénégal et Casamance, le rail fut le principal vecteur constitutif du territoire sénégalais et I 'épine dorsale de l'économie arachidière jusqu'à l'indépendance du pays. D'abord complété par un réseau routier modeste pour les besoins de l'exploitation de la graine, le chemin de fer fut rapidement concurrencé puis dépassé par les transports routiers. Ainsi la voie ferrée «Dakar-Nigen», axe historique reliant Dakar à Bamako et autrefois ciment de l'unité nationale, est doublée, sur toute sa longueur depuis I 999 par la RN I de Dakar jusqu 'à la frontière malienne. Aujourd'hui les deux axes ne sont concurrents que sur le trafic de transit à destination du Mali et ne sont plus complémentaires sur rien. L'arachide est transportée uniquement par la route, comme, ensemble des marchandises (y compris les pondéreux) destinées au marché intérieur. De même les voyageurs se déplaçant à l'intérieur du Sénégal n 'empruntent plus le train Les revalorisations récentes des deux axes semblent plus attiser la concurrence que leur complémentarité: après le revêtement du dernier tronçon de la RN I en 1999, une partie plus importante du trafic de transit Dakar-Mali emprunta la route" [Lesourd, Ninot 2006, p. 95].

\section{Riferimenti bibliografici}

Almeida-Topor Hélène, Chanson-Jabeur Chantal, Lakroum Monique (1992). Les transports en Afrique, XIX et XX èmes siècles. Paris: L'Harmattan.

Bigon Liora (20 I6). French colonial Dakar.The Morphogenesis of an african regional capital. Manchester: University Press.

Chaleard Jean-Louis, Chanson-Jabeur Chantal, Beranger Chantal (2006). Le Chemin de fer en Afrique. Paris: Karthala, Prodig et Sedet.

Djib Faye (2013). Urbanisation et dynamique des transports "informels" et desmobilités dans les villes secondaire sénégalaises: les cas de Touba, Thiès et Saint Louis. Géographie. Université Michelde Montaigne-Bordeaux III.

Dupon Jean-François (1964). Tambacounda, capitale du Sénégal oriental. In: Cahiers d’outre-mer. № 66 - I7e année, Avril-juin: <https://doi.org// 0.3406/caoum. 1 964.2337>.

Jaekel Francis (1997). The history of the Nigerian railway. Ibadan: Spectrum Book.

Kimba Idrissa (1997). L'échec d'une politique d'integration: les projets ferroviaires et le territoire du Niger (I 880-1940). In Becker Charles, Mbaye Saliou, Thioub Ibrahima. AOF: Rèalitès et hèritages, societès ouest africaines et ordre colonial. 1895 - 1960. Dakar: Direction des archives national du Sénégal.

Lesourd Michel, Ninot Olivier (2006). Un divorce au Senegal. Le chemin de fer Dakar-Niger et la Route National. In AlmeidaTopor Hélène, Chanson-Jabeur Chantal, Lakroum Monique (eds.). Les transports en Afrique, XIX et XX èmes siècles. Paris, L'Harmattan.

Mamadou Daye Sow (2005). Les transformations urbaines dans les villes du sud: l'exemple de Saint-Louis du Senegal. Geographie. Universite Toulouse le Mirail - Toulouse II.

Monson Jamie (2009). Africa's freedom railway. How a Chinese Development Project Changed Lives and Livelihoods in Tanzania. Bloomington: Indiana University Press.

Pourtier Roland (2007). Les chemins de fer en Afrique subsaharienne, entre passé révolu et recompositions Incertaines. Belgeo: $<$ http://journals.openedition.org/belgeo/ | 266>.

Robinson Julia Coyner (2007). "Tout Travail Doit Nourrir Son Homme"The Dakar-Niger Railroad and the 1947-I948 Strike in the Political and Labor History of Senegal"'. In Independent Study Project (ISP). Collection 2007: <https://digitalcollections.sit. edu/isp_collection/|89>.

Sakho Papa (199I). Evolution des escales ferroviaires du bassin arachidier oriental jusqu" a la fin des annees 1980 (Senegal). Dakar: Universite Cheikh Anta Diop de Dakar.

Zaurrini Mauro (20 I5). Una nuova stagione per le ferrovie africane. In Africa e Affari,Anno 3 numero 8, Internationalia, Roma, p. 4.

\section{Autore}

Sebastiano Nucifora, Università degli Studi Mediterranea di Reggio Calabria, sebastiano.nucifora@unirc.it

Per citare questo capitolo: Nucifora Sebastiano (2020). Dakar-Niger. Paesaggi, città, villaggi, architetture lungo la ferrovia del Sahel: una ricerca in corso/Dakar-Niger. Landscapes, cities, villages, architecture along the Sahel railroad: a research in progress. In Arena A., Arena M., Brandolino R.G., Colistra D., Ginex G., Mediati D., Nucifora S., Raffa P. (a cura di). Connettere. Un disegno per annodare e tessere. Atti del $42^{\circ}$ Convegno Internazionale dei Docenti delle Discipline della Rappresentazione/Connecting. Drawing for weaving relationships. Proceedings of the 42th International Conference of Representation Disciplines Teachers. Milano: FrancoAngeli, pp. 3590-3613. 


\title{
Dakar-Niger. Landscapes, Cities, Villages, Architecture along the Sahel Railroad: a Research in Progress
}

\author{
Sebastiano Nucifora
}

Abstract

In 1885 the French colonial regime inaugurated the railroad connecting Dakar to Bamako. Today, China invests in Africa with a financial plan that, in 2018 , is worth over 60 billion dollars. A colonialism no longer political but economic, which translates into practice a simple equation: raw materials in exchange for infrastructure. Among the latter, China pays particular attention to the strengthening of the African railroad lines, such as the one between Dakar and Bamako travelled by the legendary Koulikoro train, the restructuring contract of which was assured in 2015 by the China Railroad Construction Company for almost 3 billion of dollars. It goes without saying that such an investment will affect the socio-economic future of the area. It will definitely revolutionize a territory of considerable extension, starting from the many urban centers along the railroad. From Keffrine to Tambacounda, these centers are still struggling between the spatial and conceptual dimensions of the large village and those of the small city.

The ongoing research aims to investigate and classify the centers along the railroad and the role that the latter has had in their urban history, as well as to propose project hypotheses starting from the large voids present in the railroad areas marked by a collapsing colonial architecture. These projects aim to become potential matrices of future scenarios for a really sustainable development, one that is accepted by the local communities.

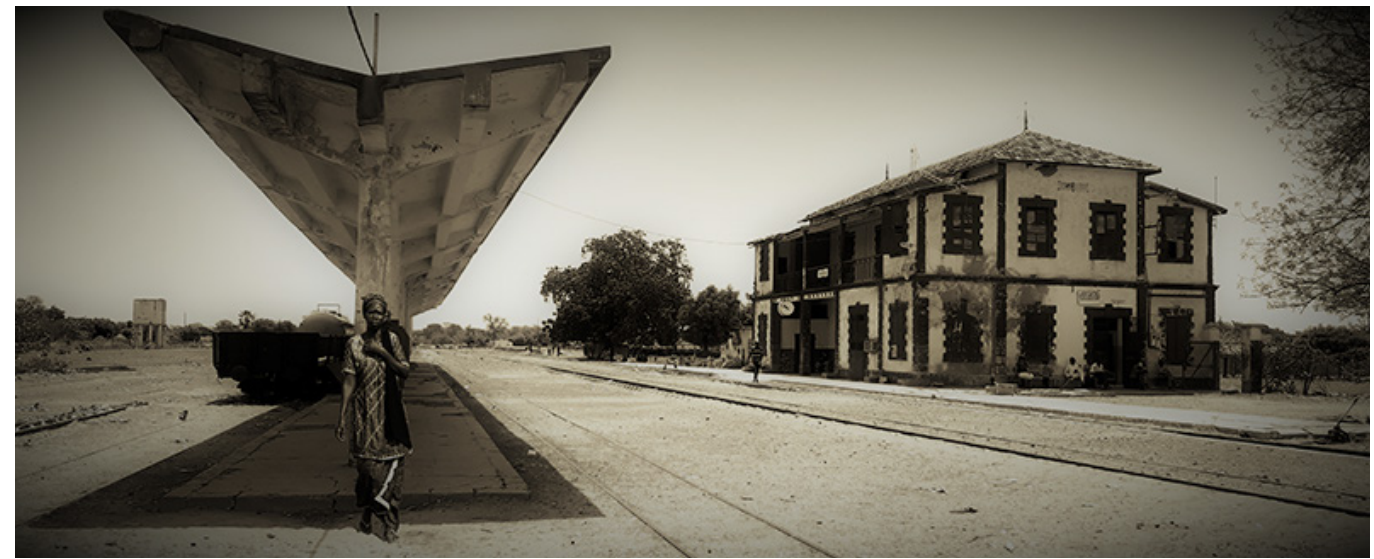




\section{Introduction, research hypothesis and methodology}

The $263 \mathrm{~km}$ of railroad connecting the new capital city of Senegal to the old French one, Saint Louis, was inaugurated in Dakar on July 6, 1885. This was the first of three streches provided for in the 1879 Freycinet plan. The project included a second track -from the capital of Mali, Bamako to Kayes, on the border between the two states $(498 \mathrm{~km})$ and a third one connecting the first two- from Kayes to Thiés and then back to Dakar (648 km). This project was one of the few actually implemented in Africa in its entirety with the construction of both the second and the third stretches (respectively, from I88I to 1904 and from 1905 to 1923) [I].

The railroad was part of a wider plan of infrastructural penetration of French-Africa, capable, in the intentions of the colonizers, to integrate, economically and militarily, the territories of the north, on the Mediterranean arc, with those of the west, within the continent up to the Gulf of Guinea. The Maghreb and sub-Saharan territories, separated not only physically from the desert, would have been crossed by two routes, the first from south to north, trans-Saharan, and the second, from west to east, trans-African. The enormity of the enterprise and the complex colonial events allowed only partially to implement the plan, leaving unfinished the dream of a railroad crossing of the great Erg.

All the tracks brought to completion have profoundly altered the settlement logic of the territories. Especially the Saint Louis-Dakar-Bamako has represented, as long as it remained active, the route with greater functional coherence, being capable of connecting the Senegalese ports on the Atlantic ocean with the banks of the great Niger River.

More than a hundred years later, having gained political independence from the European colonizers, sub-Saharan Africa is now subject to a new form of colonialism by China, owing to a 20 I 8 investment plan worth over 60 billions of dollars. The underlying equation is as elementary as it is effective: raw materials in exchange for infrastructure.

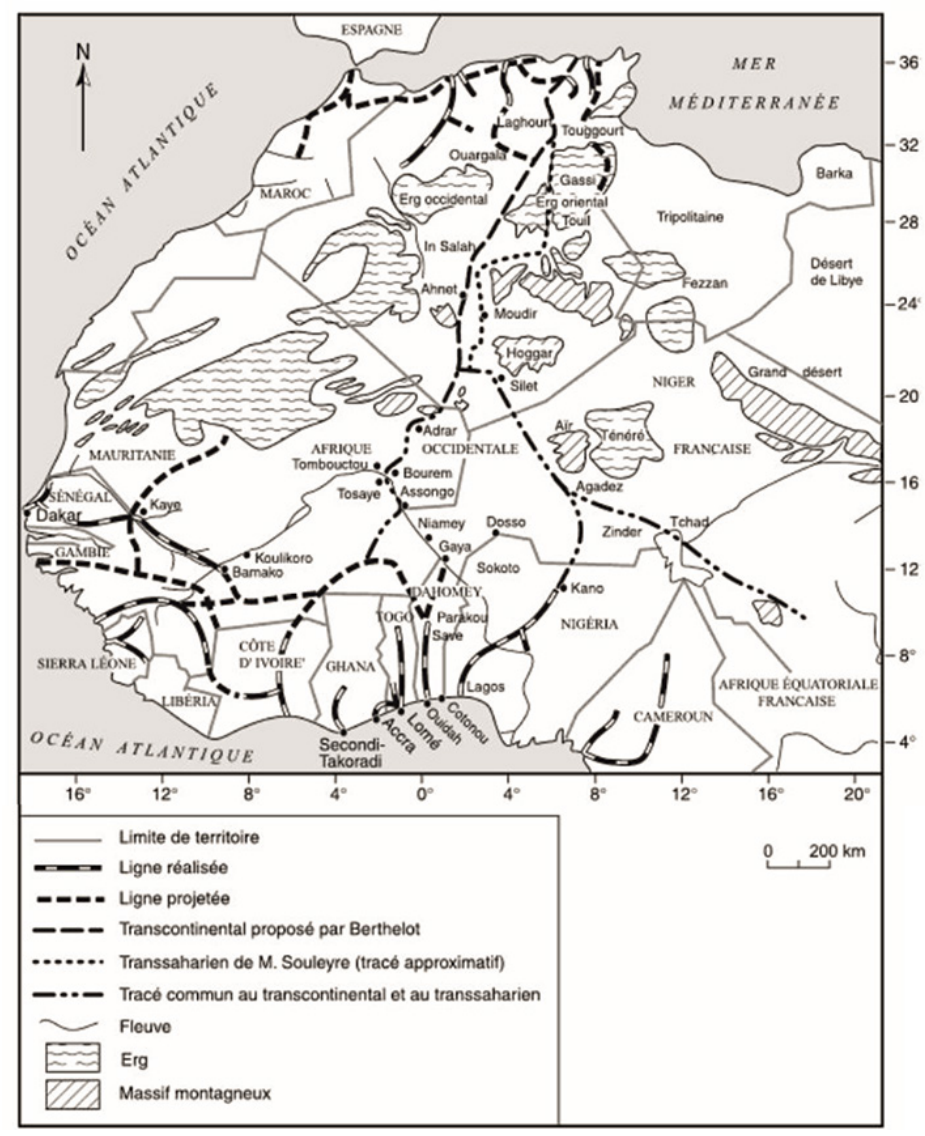


Among these infrastructures, particular attention is paid to the upgrading of the railroad tracks [2]. Many of them are currently abandoned, such as the one between Dakar and Bamako traveled by the legendary Koulikoro train from early Twentieth century through the beginning of the Twenty-first [3]. Of this track the Chinese company China Railroad Construction secured a restructuring order for almost 3 billion dollars in 20 I 5. The interests that move this operation are bound to change again the destinies of a territory of considerable extension.

From Kaffrine to Tambacounda, from Kita to Badinko, the city centers along the railroad oscillate between the size of a large village and that of a small city, having been trapped in the no-mans land between a French colonial approach and an informal development due to the lack of an effective post-colonial planning and the ancestral rejection of the model imposed by colonialism itself.

In its first stage, the ongoing research proposes to investigate and classify the urban centers and villages present on the Dakar-Bamako route falling in the Senegalese territory. City centers following one another along the path parallel to the Atlantic coast between Dakar and Saint Louis will be the subjects of its subsequent phase, toghether with those lying in the Malian territory.

The study highlights the founding role of the railroad in the configuration of the urban fabric, while at the same time it detects and catalogues the battered colonial architecture that are interspersed in the territory.

In an attempt to patient reconnecting the pre to the post-colonial history of a fragile territory that is still looking for its own identity, the research aims at the realization of projects of true sustainable development that are accepted by local communities. Its philosophy is radically opposed to that of the new Chinese competitors, whose scenarios are cearly aimed at making a clean sweep of the existing state of the art.

The methodology consists of five steps: I) archival research of bibliographic, iconographic and cartographic material [4];2) inspections and photographic investigations in situ; 3) direct survey with traditional and / or photogrammetric method of the most important colonial architectures [5]; 4) return of surveys and construction of digital models; 5) critical classification of the city centers and of their architectures [6].
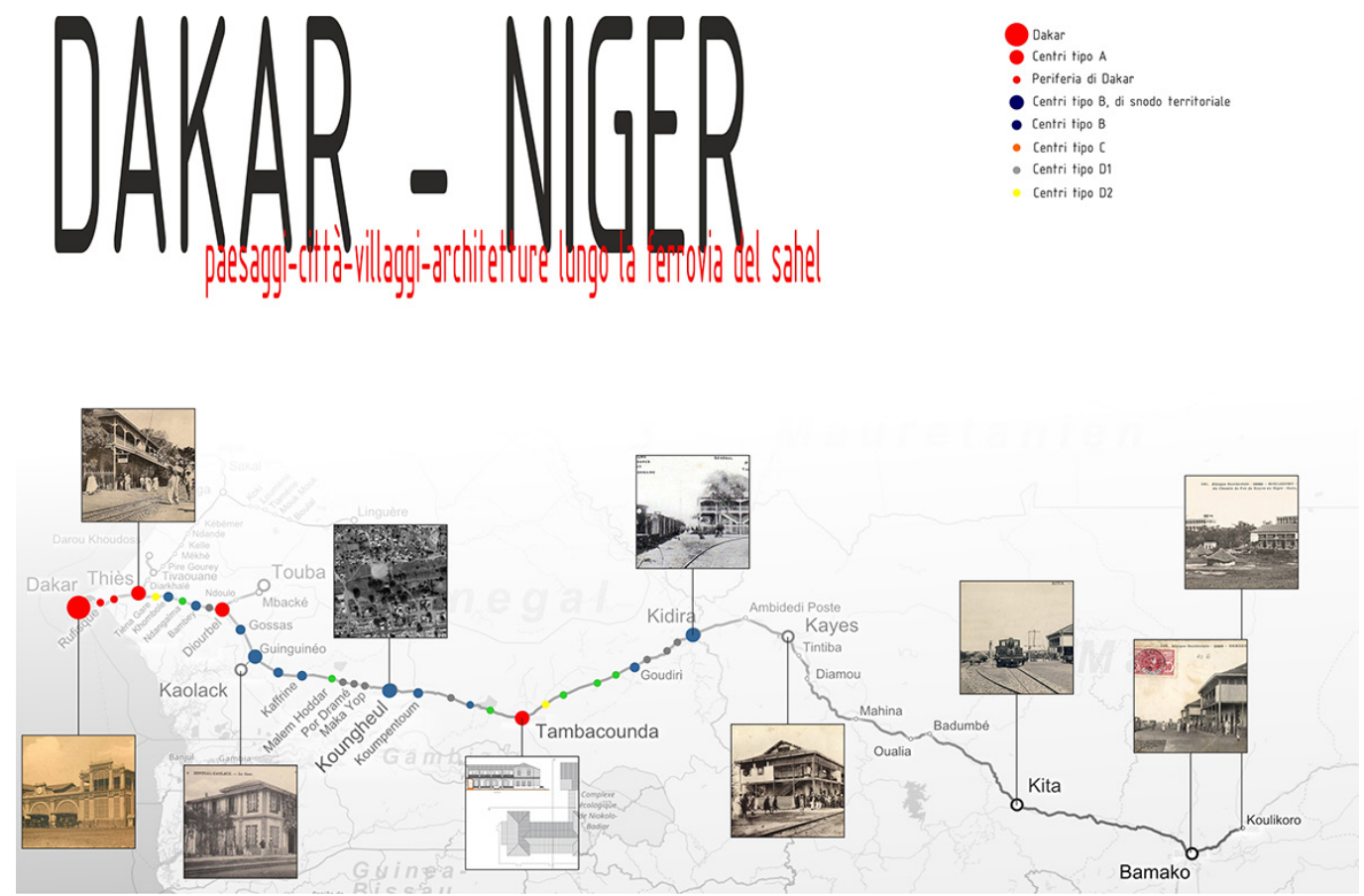


\section{Cities, villages}

At the time of the completion of the railroad, Thiés, the most populous city on the route, was a small serer village where the French had recently installed a military base. The population count did not exceed I 50 units [7]. With the exception of the two capitals, agglomerations definable as 'urban' were absent in the maps between Senegal and Mali. As a matter of fact, it is the building of the railroad which determines the birth of the centers along its route. This should not feed the theory that the 'city' is a creature extraneous to the pre-coIonial sub-Saharan habitat model. This is testified by the history of Bamako, or that of the legendary centers of the kingdoms of Mali and Ghana. It can be demonstrated that, where it was possible to find stone materials, the African peoples were capable to build monuments no less important and durable than those of other cultures. If the territory in question was structured by scattered rural settlements, this is mainly due to cultural and anthropological factors deriving from the more or less sedentary characteristics of the ethnic groups that lived there, as well as, obviously, to a more strictly natural fact.
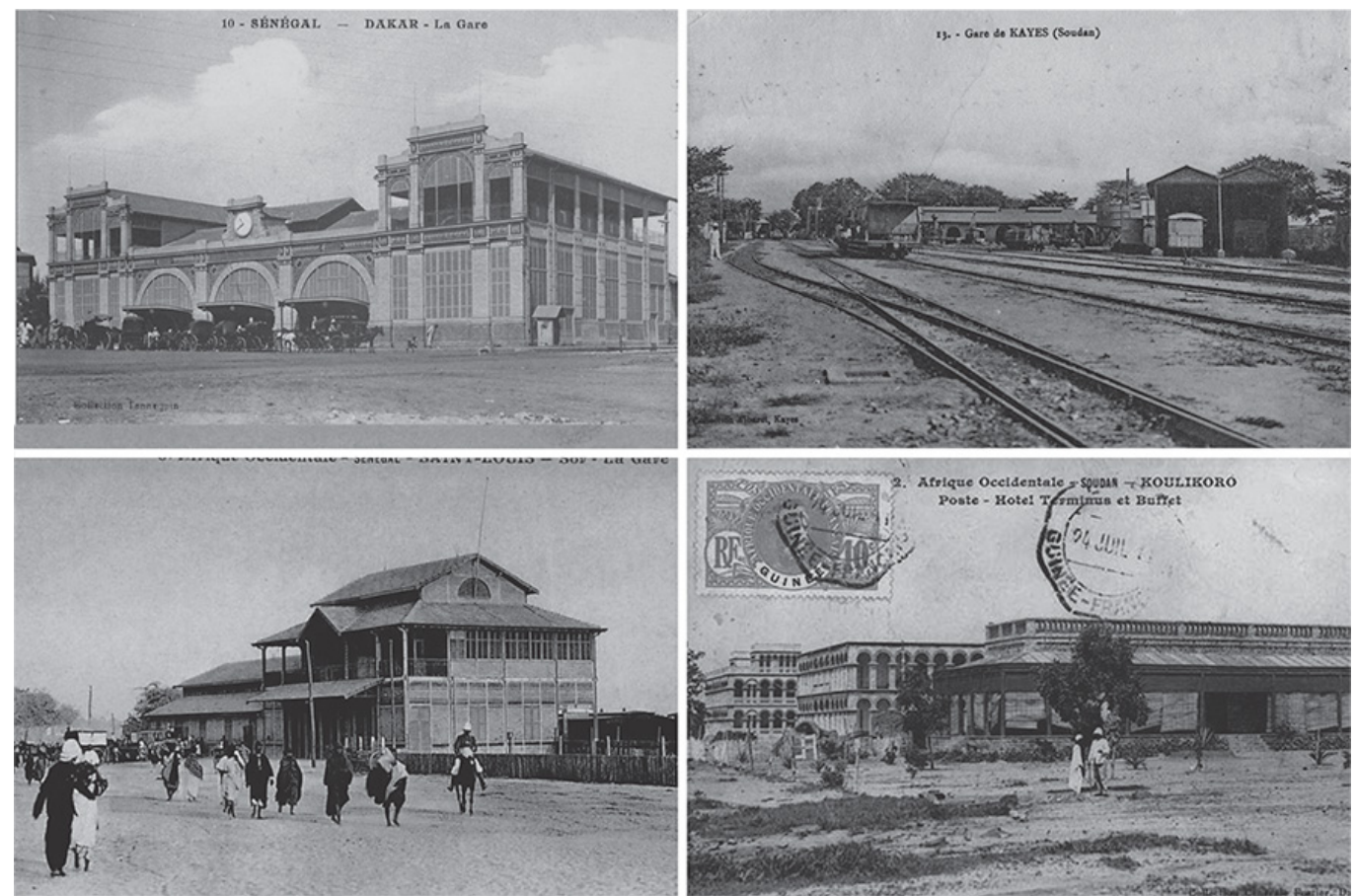

The railroad wall is almost always located in a virgin land. As a result, it usually becomes the generating element of a new inhabited area which acts as a catalyst centre for the rural populations of the surrounding areas. The colonial city will be planned on the "measure" of the valley, with a rigid orthogonal mesh system, as it is recorded in the majority of the Senegalese centers. The case of the centers in Mali is different, because the more complex morphology due to the presence of rivers and hills, combined with an indigenous 'urban' culture, will give rise to more complex urban plants.

As far as the Senegalese urban centers are concerned [8], the classification was based at the intersection of three parameters: I) the size and territorial importance of the urban center, 2) the typology of the urban system, and the configuration of the railroad area based on the presence or the absence of service structures. 
Fig. 4. Schemes of some A type and $B$ type centres. In black the French urba plant with the large void of the railway area. In light grey the market area.
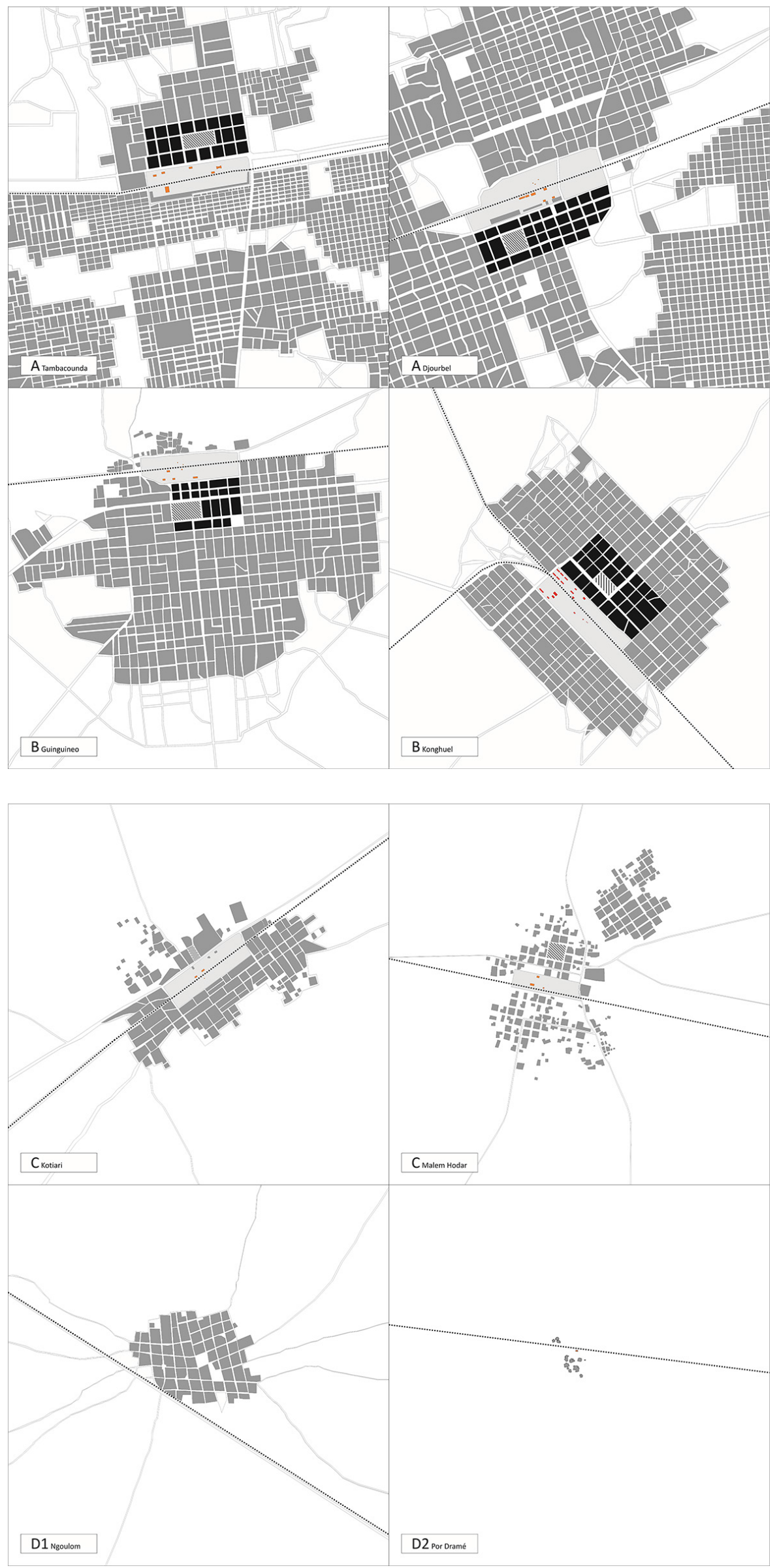
Along the way, four types can be identified:

A-Type centers: Thiés, Diourbel, Tambacounda. These are centers of medium or great importance which, precisely because of their strategic territorial position, were probably already rural villages before the colonial presence. The railroad track confirms their position but, with the planimetric definition of the station's wall, an orthogonal layout is established. As a result, the transformation of their features from rural to urban supplants the typology of the spontaneous village. The urban mesh designed by the French defines the size of the block but, with the notable exception of those lots whose the perimeter is delimited by the administrative buildings of colonial blueprint, the outline of the lot actually becomes a low "fence". As in tradition rural villages, inside this new fence buildings are freely arranged. Thiés, also by virtue of its proximity to Dakar, is certainly the most important center, both in terms of strategic position and extension, and is the only one that can rise to the rank of city.
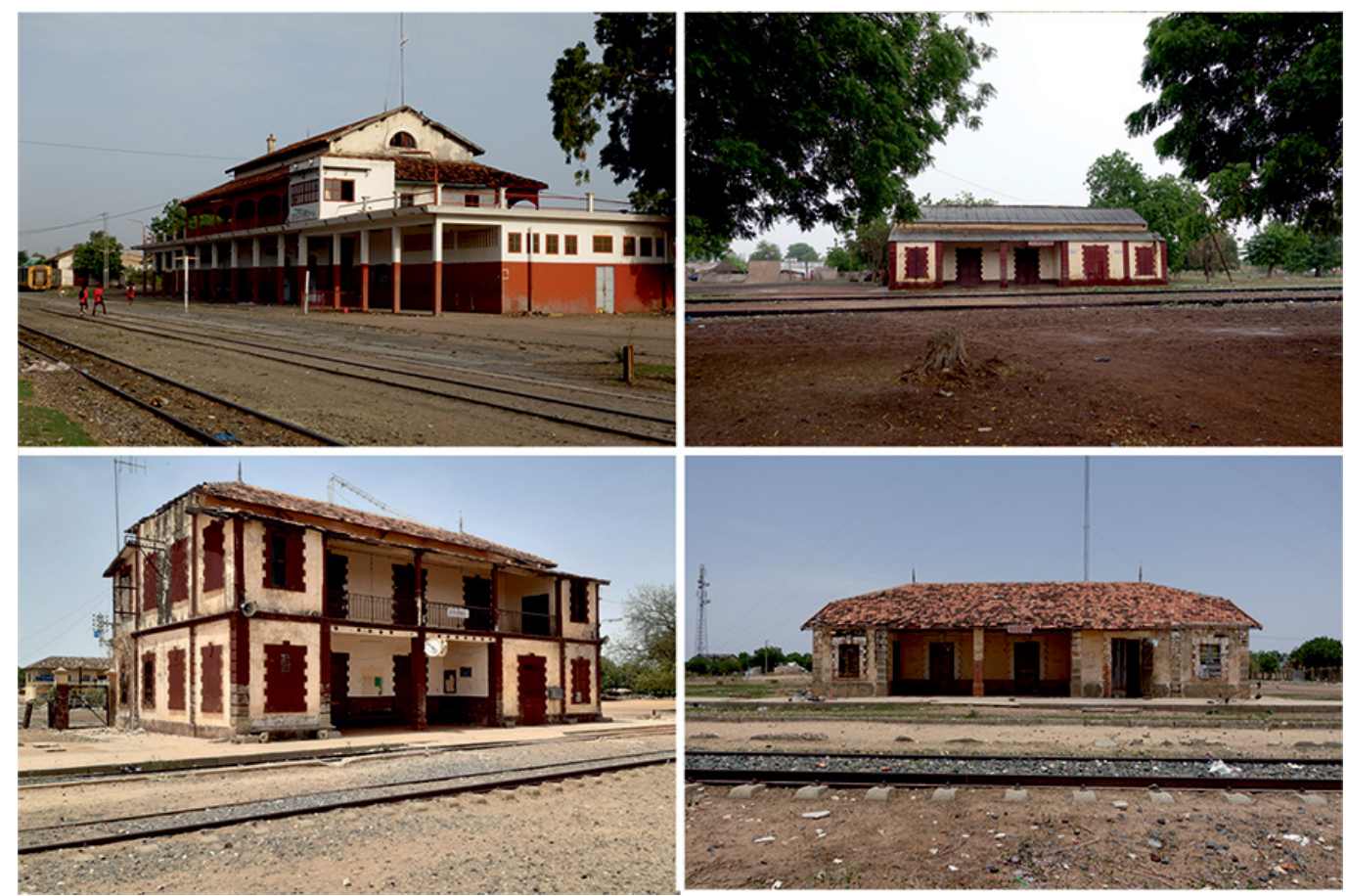

Although the remarkable urban development has produced a multipolar fabric, resulting from the central position of the center respect to the territory, it is still clearly recognizable the original plant pole of the French colonial plan, of which the railroad is the pivotal element. The urban plants of Diourbel and Tambacounda are more regular. Also these two towns are characterised as territorial junctions: towards the holy city of Touba the first, towards Casamance the second.

B-Type centers: Khombole, Bambey, Gossas, Guinguineo, Birkelane, Kaffrine, Kongheul, Koumpetoun, Goudiri and Kidira. These are centers of small and medium size and importance and are, apart from the exception of Kaffrine [9], newly founded urban centers. The most important port was Guinguineo, at the junction between the Kaolach route and Gambia. Built in site considered of strategic importance by the French, they are characterized by the regular fabric generated by the position and size of the railroad wall. The urban layout is always orthogonal. When consistent deviations are found with respect to the urban mesh, this is due to the orientation of the RNI [IO] national road, which in parts does not remain parallel to the railroad. 
Among these centres, an anomalous case is represented by the urban plant of Kidira, border town between Senegal and Mali which, following the course of the river Falémé, border between the two states, follows different settlement logics. In all these centres, the railroad area has a functional complexity that varies on a case-by-case.

C-Type centers: Dangalma, Malem Hoddar, Sinthiou Malem, Koussanar, Kotiari, Bala, Boughieul Bamba. They are small-sized centers that have grown less than those of the B-type. Here the presence of the railroad valley is still perceived, and the planning of the orthogonal mesh is legible.

Among these, Boughiel Bamba is an exception, where the planimetric footprint of the settlement remains that characteristic of the rural village. In the railroad area there is only the station building and, at most, some warehouses.

D-Type centers: The numerous very small centers that can be defined as villages, which almost invariably developed after the building of the railroad. In turn, they can be distinguished into two types: DI, where planning is minimal planning and lots are divided according to the orthogonal mesh -as in Ngoulom; and D2, where the structure of the rural village is intact as in Por Dramé.

Fig. 7. Trains Warehouse of Tambacounda and Railroadmen's Houses of Gossas, Bambey, Kaffrine.
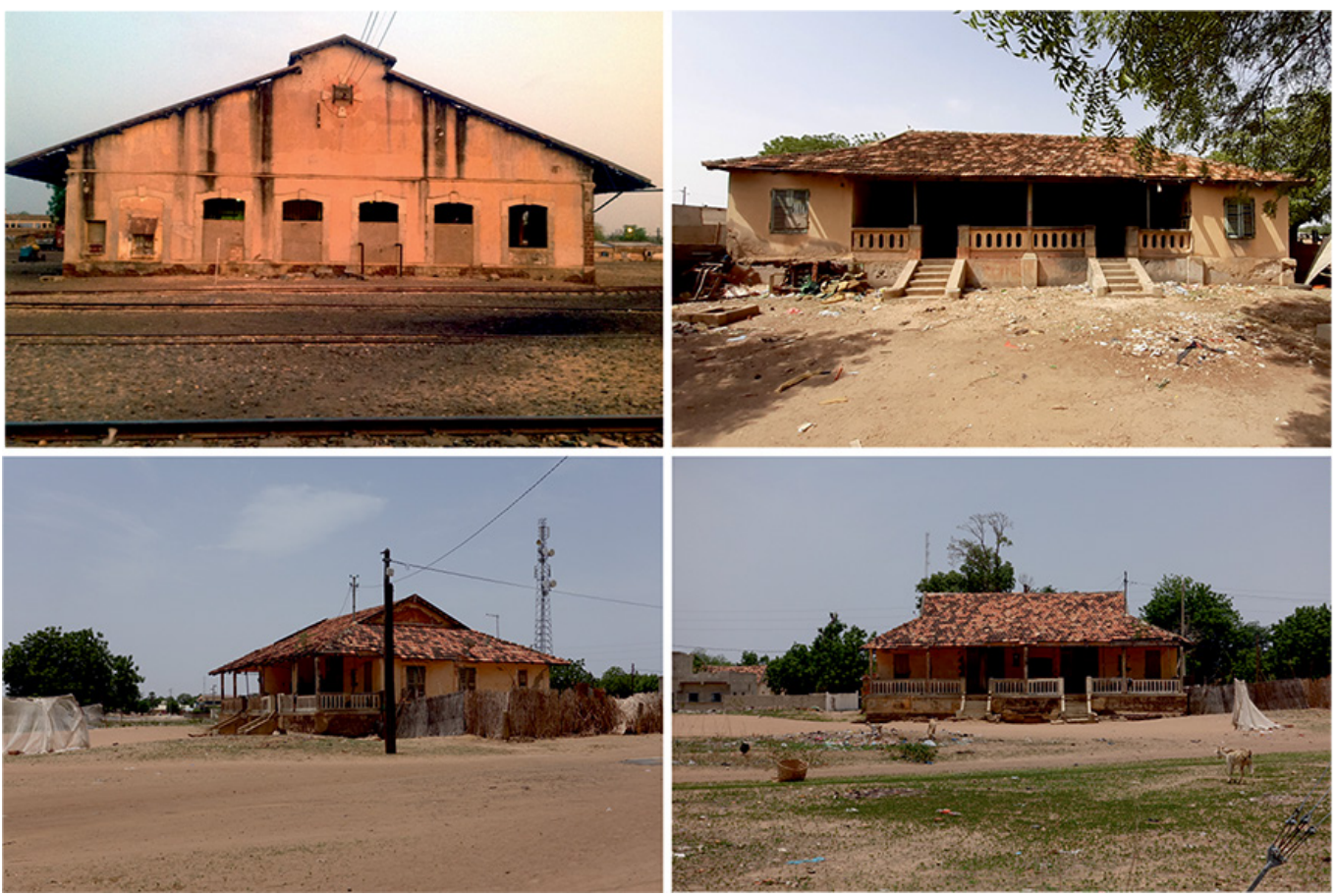

These are not places that the colonial project considered strategic for the control and dynamics of the territory's transport links, and there is no building structure linked to the railroad except, sometimes, only the station building as, for example, in Lagnar, Maka Yop and Por Dramé.The railroad has had a catalytic function here, leading to the formation of villages straddling the line itself, where nothing it was not previously present.

Both in centers of the A and B type, the most relevant feature is the presence of the "large void' of the railroad area.

The size of this void is constant in all centers, developing in a rectangle that varies from 700-800 m in length, to 250-300 meters in width. The length measurement represents the front of the colonial city, which normally settles on only one of the two sides of the valley, with the positioning of the administrative buildings and the location of the market area in the immediate vicinity. 
Fig. 8. Hotel de la Gare of
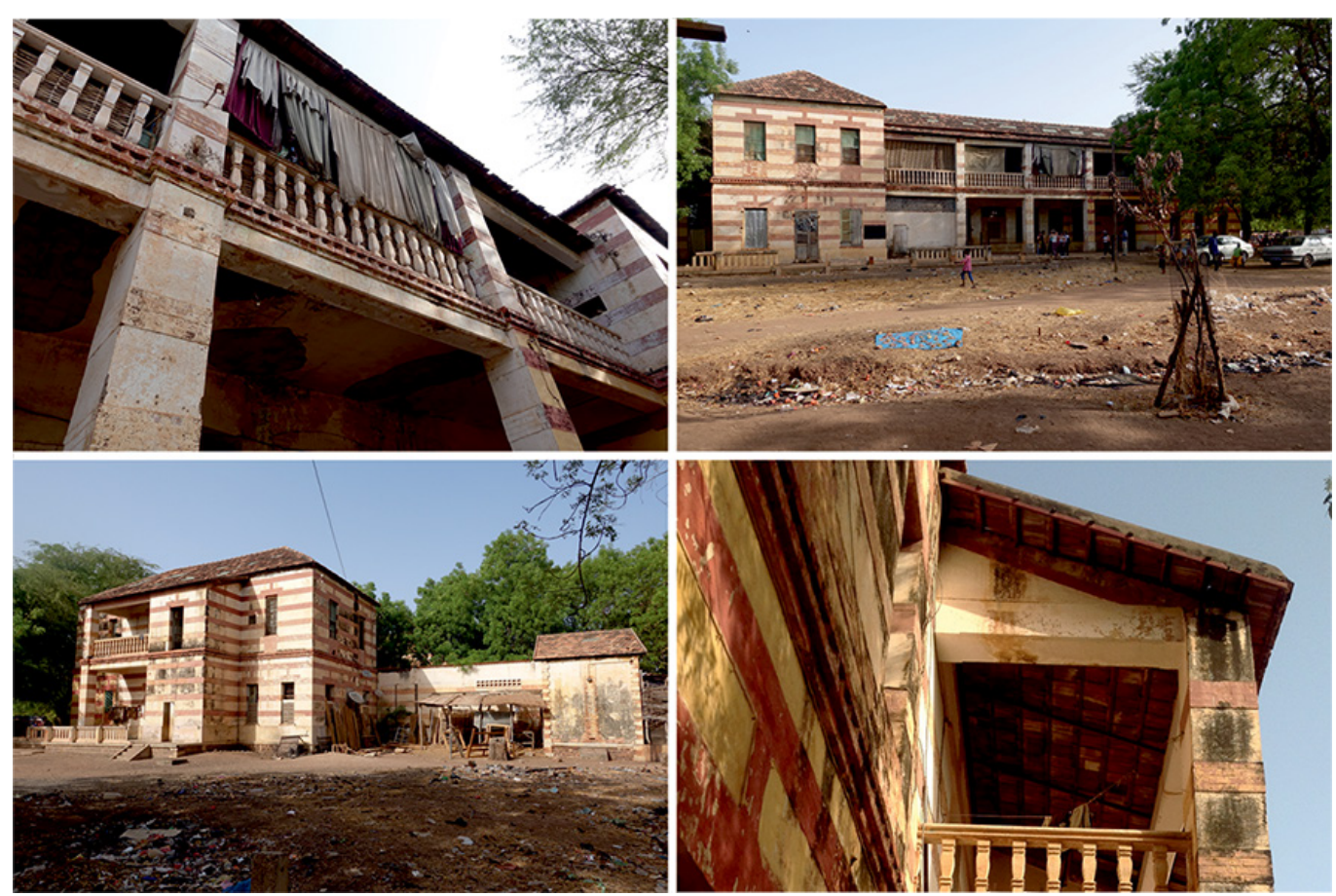

Fig. 9. Prefecture of
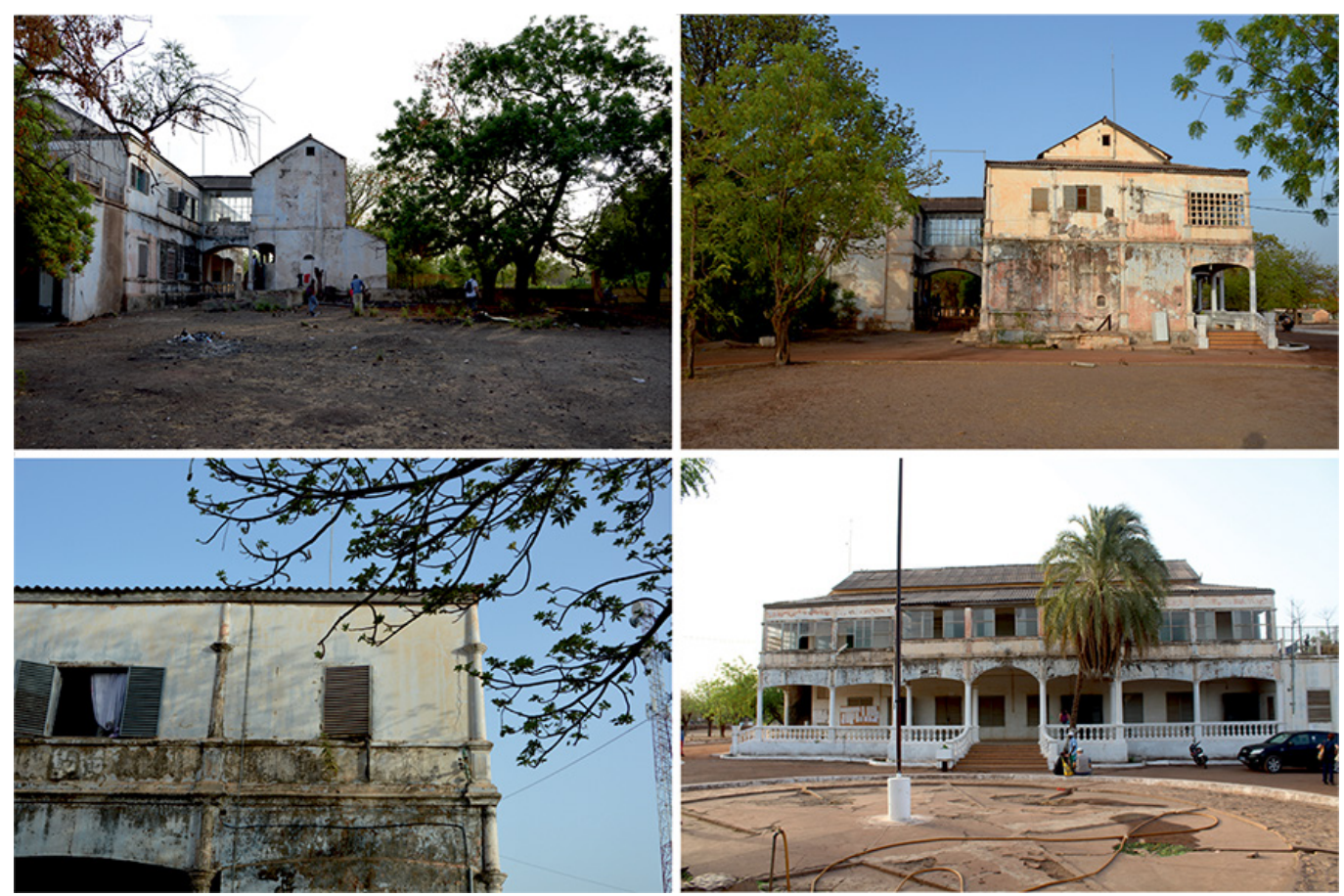
On the opposite side, divided by the railroad, in some cases, develops the 'African city', characterized by a more minute fabric. This type of division between colonial city and African city is very evident in the case of Tambacounda. Here, to the north of the railroad line are the administrative buildings, some of which are of considerable architectural and typological interest, such as the Prefecture, in lots with a square orthogonal mesh of 95 metres on one side, while to the south the minute fabric of the dwellings develops within rectangular lots of $50 \times 30$ metres.
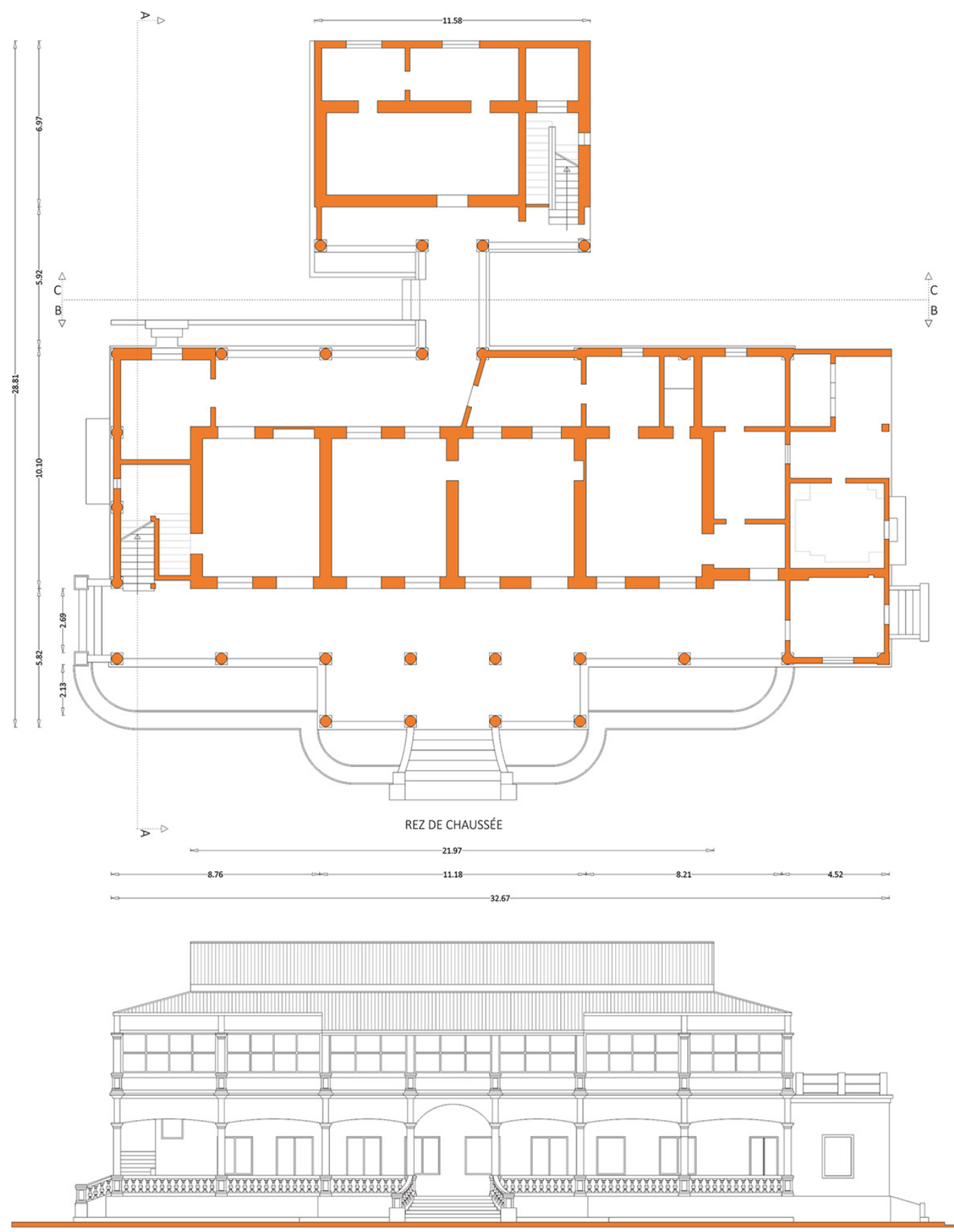

FAÇADE SUD 


\section{The architectures}

The great void is occupied by the colonial buildings of the railroad, divided by functional typologies but united by an architectural language and a common use of materials. In its complete configuration, which can only be found in Tambacounda, the following can be listed:

Station. It is a one-storey or, in the most important centers, a double storey building, characterized by the presence of a loggia area.

Trains warehouse. It is the large hangar located in a decentralized position with respect to the wall.

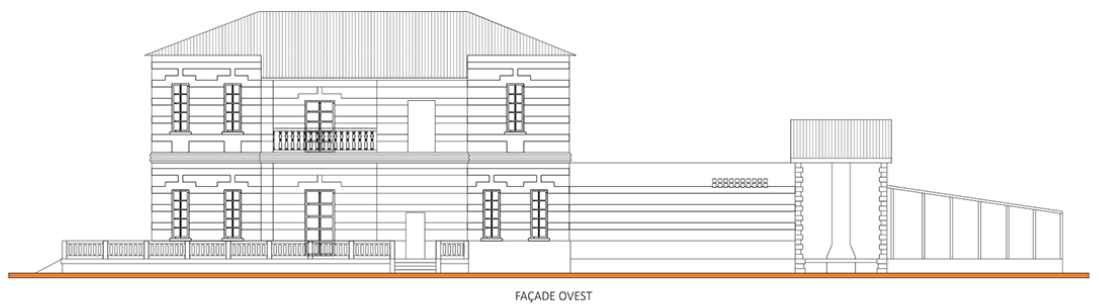

FACADE OVEST

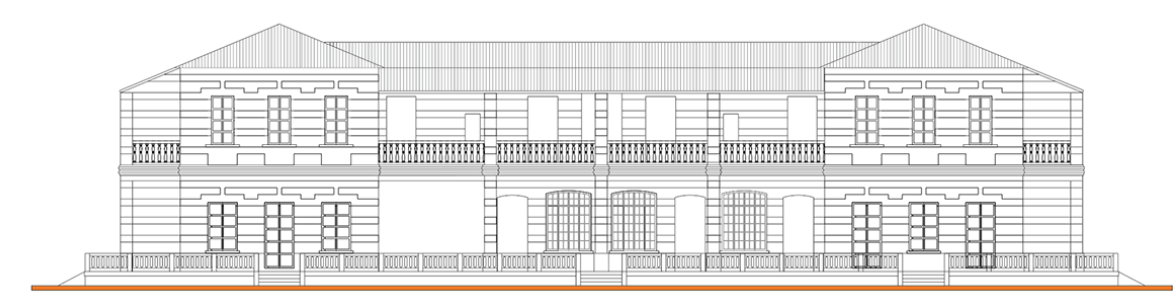

FAGADE NORD

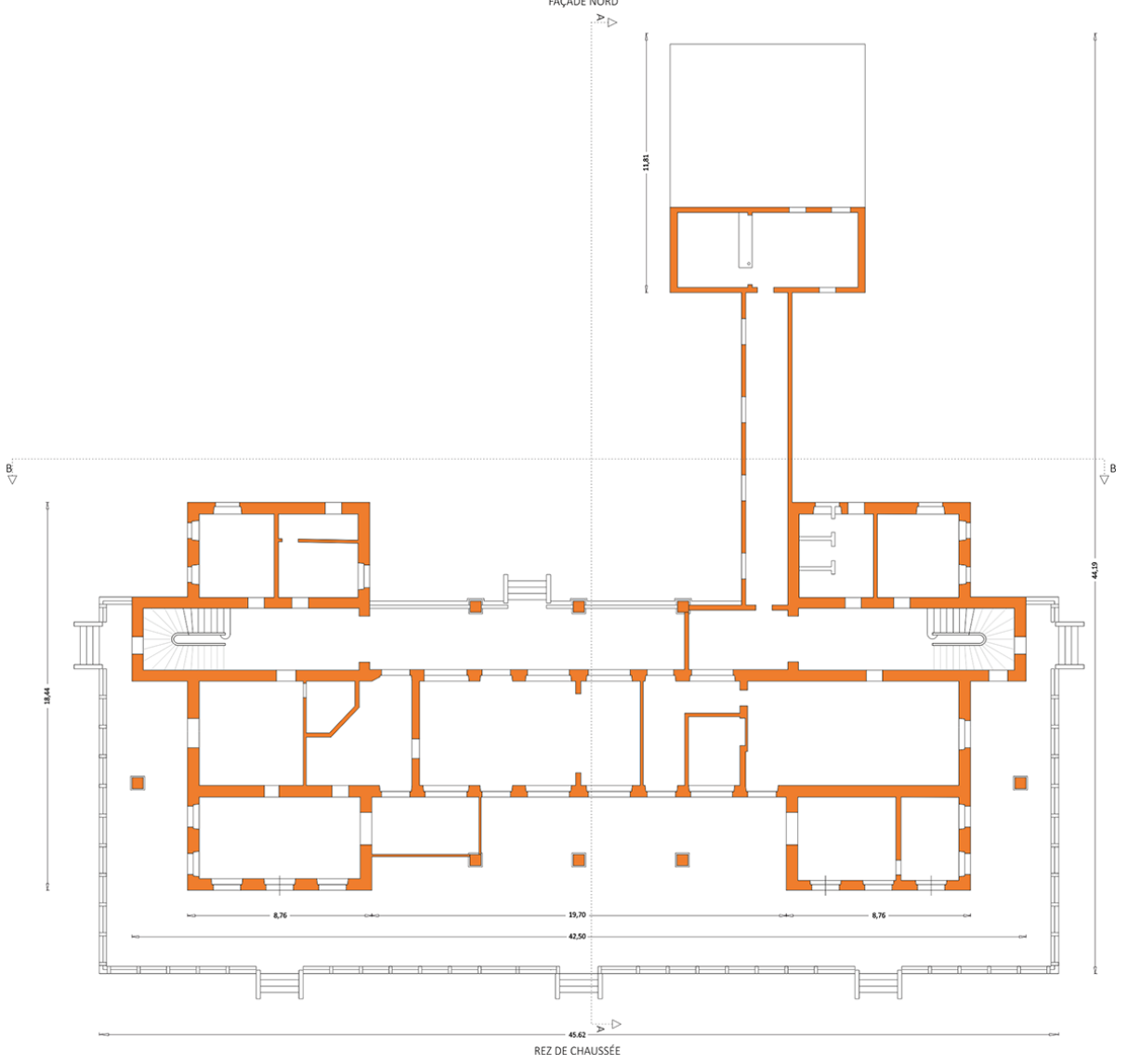


Goods warehouse. It is a single-storey building with a single compartment, in variable numbers according to the importance of the airport.

Offices and housing of railroad workers. Normally located along the outer edge of the railroad valley, in contact with the main road in the center, they are of different types, one or two storey. Station hotel. Only in Tambacounda there is the presence of a Hotel de la gare within the railroad wall. The architectural language makes it clear that the station belongs to the same project.

Water tower. With a cylindrical shape supported by series arches. There can be more than one.

Toilet. Located outside the buildings, in small isolated huts.

Places of worship. Small open enclosures, with a sort of apse facing Mecca.

\section{Conclusions}

According to our investigation, many of the buildings associated with the railroad are considerer, at least on paper, architectural assets that are bound by the local government, even when, as it is often the case, they are in a state of total abandonment. The restoration and rehabilitation of these architectures can be an important opportunity for many of the city centres, especially when they are considered within a general projest of urban reconfiguration of the 'great void'. It is clear that, by virtue of the current changing needs, the latter represents a strategic area to be reconsidered in view of a probable reactivation of the railroad. Indeed, appropriate projects would be fundamental to the creation of new redevelopment opportunities, capable of integrating old colonial interventions with the shared needs of local communities.
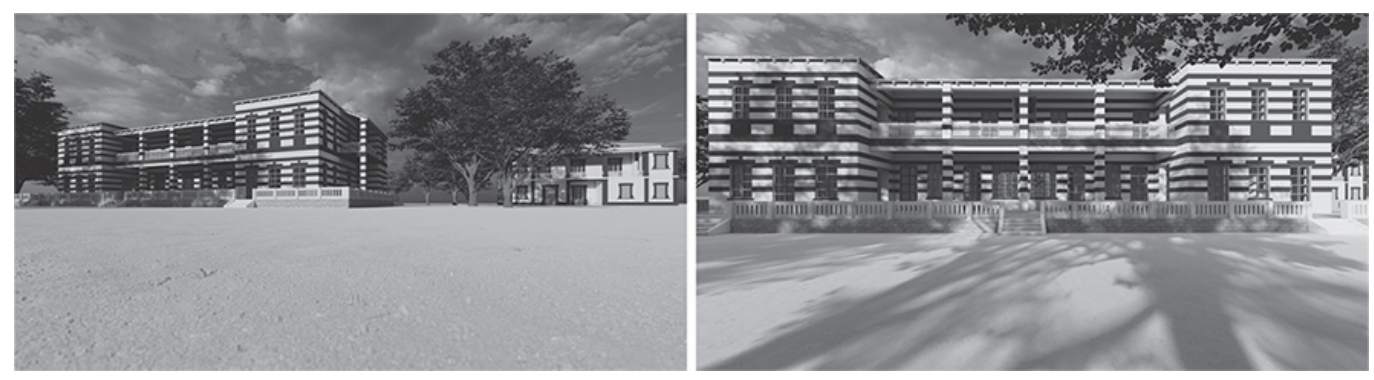

\section{Notes}

[1] Three other minor branches will later be built in the Senegalese territory: the Guinguineo-Kaolack (1912), the LougaLinguere (1928) and the Djourbel-Touba (1931).

[2] "There are at least three indicators that lead us to believe that African railways are at the dawn of a new season after decades of abandonment. The first is [...] the vocation for the export of raw materials [...] All these goods will need to reach the ports quickly and safely. The second element is the gorwth of the African population and the continuous urban development. African cities will become bigger and bigger, and metropolises or satellite cities will be more numerous. A phenomenon that is pushing many governments to project subways, tramways, light railways [...] The third element is the greater weight of the intra-African trade [Zaurrini 2015, p. 4].

[3] Name by which the convoy was known and which takes up that of the terminus city, the Niger river port, located a few tens of $\mathrm{km}$ east of Bamako.

[4] In addition to the web, this phase was carried out in the offices of the Senegalese administrations concerned, includ-ing the library of the Institute Politechnique Panafricain in Dakar. In this sense, the lack of any graphic documentation is highlighted. It reinforces the need for an urgent cataloging and survey of the colonial architectures in question. A sub-sequent phase of archival research, not yet completed, deals with the search for nineteenth-century French manual production, to which the architecture of the Senegalese stations refer with all certainty.

[5] Two inspections were carried out (July 2017, August 2019), retracing the railway line from Dakar to Goudiri, carrying out an exhaustive photographic campaign of all the centers and, as a sample, the surveys of a good number of archi-tectures. A third inspection with the relevant survey campaign is expected by 2020.

[6] The phase of restitution and construction of digital models, as well as the critical classification of urban centers and architectures, is underway. 
[7] With more than 1,000,000 residents, Thiés is currently the third largest city in Senegal by population after Dakar and Saint Louis.

[8] The research does not deal with an investigating of the capital Dakar since there, of course, the dynamics of settlement are much more complex and go way back in time to be traced to the presence of the railway structures only.

[9] Here the existence of a serer ethnic village is certain.

[ I 0] Route National I crosses Senegal from west to east and is, in fact, responsible for the progressive decay of rail transport as Michel Lesourd and Olivier Ninot explain well: "Après les fleuves Sénégal et Casamance, le rail fut le principal vecteur constitutif du territoire sénégalais et I 'épine dorsale de l'économie arachidière jusqu'à l'indépendance du pays. D'abord complété par un réseau routier modeste pour les besoins de l'exploitation de la graine, le chemin de fer fut rapidement concurrencé puis dépassé par les transports routiers. Ainsi la voie ferrée «Dakar-Nigen», axe historique reliant Dakar à Bamako et autrefois ciment de I 'unité nationale, est doublée, sur toute sa longueur depuis 1999 par la RN I de Dakar jusqu 'à la frontière malienne. Aujourd'hui les deux axes ne sont concurrents que sur le trafic de transit à destination du Mali et ne sont plus complémentaires sur rien. L'arachide est transportée uniquement par la route, comme, ensemble des marchandises (y compris les pondéreux) destinées au marché intérieur. De même les voyageurs se déplaçant à l'intérieur du Sénégal n 'empruntent plus le train. Les revalorisations récentes des deux axes semblent plus attiser la concurrence que leur complémentarité: après le revêtement du dernier tronçon de la RN I en 1999, une partie plus importante du trafic de transit Dakar-Mali emprunta la route" [Lesourd, Ninot 2006, p. 95].

\section{References}

Almeida-Topor Hélène, Chanson-Jabeur Chantal, Lakroum Monique (1992). Les transports en Afrique, XIX et XX èmes siècles. Paris: L'Harmattan.

Bigon Liora (2016). French colonial Dakar. The Morphogenesis of an african regional capital. Manchester: University Press.

Chaleard Jean-Louis, Chanson-Jabeur Chantal, Beranger Chantal (2006). Le Chemin de fer en Afrique. Paris: Karthala, Prodig et Sedet.

Djib Faye (20 I 3). Urbanisation et dynamique des transports "informels" et desmobilités dans les villes secondaire sénégalaises: les cas de Touba, Thiès et Saint Louis. Géographie. Université Michelde Montaigne-Bordeaux III.

Dupon Jean-François (1964). Tambacounda, capitale du Sénégal oriental. In: Cahiers d’outre-mer. №66 - I7e année, Avril-Juin: <https://doi.org/ / 0.3406/caoum. 1 964.2337>.

Jaekel Francis (1997). The history of the Nigerian railway. Ibadan: Spectrum Book.

Kimba Idrissa (1997). L'échec d'une politique d'integration: les projets ferroviaires et le territoire du Niger (I 880-1940). In Becker Charles, Mbaye Saliou, Thioub Ibrahima. AOF: Rèalitès et hèritages, societès ouest africaines et ordre colonial. 1895 - 1960. Dakar: Direction des archives national du Sénégal.

Lesourd Michel, Ninot Olivier (2006). Un divorce au Senegal. Le chemin de fer Dakar-Niger et la Route National. In AlmeidaTopor Hélène, Chanson-Jabeur Chantal, Lakroum Monique (eds.). Les transports en Afrique, XIX et XX èmes siècles. Paris, L'Harmattan.

Mamadou Daye Sow (2005). Les transformations urbaines dans les villes du sud: l'exemple de Saint-Louis du Senegal. Geographie. Universite Toulouse le Mirail - Toulouse II.

Monson Jamie (2009). Africa's freedom railway. How a Chinese Development Project Changed Lives and Livelihoods in Tanzania. Bloomington: Indiana University Press.

Pourtier Roland (2007). Les chemins de fer en Afrique subsaharienne, entre passé révolu et recompositions Incertaines. Belgeo: $<$ http://journals.openedition.org/belgeo/ | |266>.

Robinson Julia Coyner (2007). "Tout Travail Doit Nourrir Son Homme"The Dakar-Niger Railroad and the $1947-1948$ Strike in the Political and Labor History of Senegal". In Independent Study Project (ISP). Collection 2007: <https://digitalcollections.sit. edu/isp_collection/ | 89>.

Sakho Papa (1991). Evolution des escales ferroviaires du bassin arachidier oriental jusqu” a la fin des annees 1980 (Senegal). Dakar: Universite Cheikh Anta Diop de Dakar.

Zaurrini Mauro (20 I5). Una nuova stagione per le ferrovie africane. In Africa e Affari, Anno 3 numero 8, Internationalia, Roma, p. 4.

\section{Author}

Sebastiano Nucifora, Università degli Studi Mediterranea di Reggio Calabria, sebastiano.nucifora@unirc.it

To cite this chapter. Nucifora Sebastiano (2020). Dakar-Niger. Paesaggi, città, villaggi, architetture lungo la ferrovia del Sahel: una ricerca in corso/ Dakar-Niger. Landscapes, cities, villages, architecture along the Sahel railroad: a research in progress. In Arena A., Arena M., Brandolino R.G. Colistra D., Ginex G., Mediati D., Nucifora S., Raffa P. (a cura di). Connettere. Un disegno per annodare e tessere. Atti del $42^{\circ}$ Convegno Internazionale dei Docenti delle Discipline della Rappresentazione/Connecting. Drawing for weaving relationships. Proceedings of the 42th International Conference of Representation Disciplines Teachers. Milano: FrancoAngeli, pp. 3590-36/3. 